Portland State University

PDXScholar

Civil and Environmental Engineering Master's

Project Reports

Civil and Environmental Engineering

2014

\title{
Application of CE-QUAL-W2 on Tigris River in Iraq
}

Muhanned Al-Murib

Portland State University

Follow this and additional works at: https://pdxscholar.library.pdx.edu/cengin_gradprojects

Part of the Civil and Environmental Engineering Commons, and the Water Resource Management Commons

Let us know how access to this document benefits you.

\section{Recommended Citation}

Al-Murib, Muhanned, "Application of CE-QUAL-W2 on Tigris River in Iraq" (2014). Civil and Environmental Engineering Master's Project Reports. 9.

https://doi.org/10.15760/CEEMP.26

This Project is brought to you for free and open access. It has been accepted for inclusion in Civil and Environmental Engineering Master's Project Reports by an authorized administrator of PDXScholar. Please contact us if we can make this document more accessible: pdxscholar@pdx.edu. 
Application of CE-QUAL-W2 on Tigris River in Iraq

\section{BY}

Muhanned Al-Murib

A research project report submitted in partial fulfillment of the requirement for the degree of

\section{MASTER OF SCIENCE \\ IN \\ CIVIL AND ENVIRONMENTAL ENGINEERING}

Project Advisor:

Dr. Scott Wells

Portland State University

(C)2014 


\section{ACKNOWLEDGMENTS}

This study benefited from several people and organizations.

- Dr. Scott Wells provided guidance and advice

- The Higher Committee for Education Development in Iraq (HCED)

- My Mom

- Water Resources Ministry in Iraq

- National Center for water resources Management

- The Civil and Environmental Engineering department at Portland State University has supported my work

- My Wife 


\begin{abstract}
The Tigris River is the eastern member of the two great rivers in Iraq. Two big rivers pass through Iraq, Mesopotamia. Tigris and Euphrates Rivers with their tributaries form a major river system in the Middle East. Four riparian countries, Turkey, Syria, Iran, and Iraq, share the Tigris River basin area and Iraq has the majority of this basin area. The total length of the Tigris is 1850 $\mathrm{km}$ from which $1418 \mathrm{~km}$ is within Iraq. A study area of $880 \mathrm{~km}$ from Mosul dam to Kut barrage is modeled using a water quality CE-QUAL-W2 model. CE-QUAL-W2 is a two-dimensional (longitudinal and vertical) water quality model developed by the U.S. Army Corps of Engineers and Portland State University. W2 simulates river circulation, stage, vertical and horizontal velocities, water temperature, and a host of water quality constituents. Total dissolved solids (TDS) is the main concern in Iraq because Iraq heavily depends on its water for irrigation purposes. Therefore, this project discusses the implementation of CE-QUAL-W2 model on Tigris River to simulate flow, temperature, and TDS.
\end{abstract}




\section{TABLE OF CONTENTS}

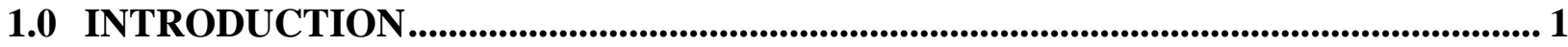

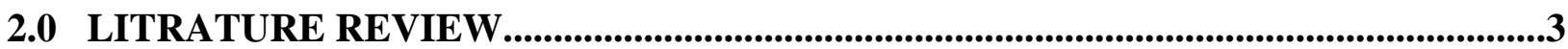

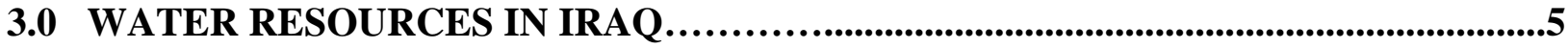

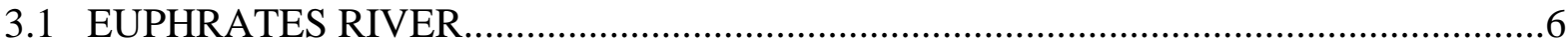

3.2 TIGRIS RIVER

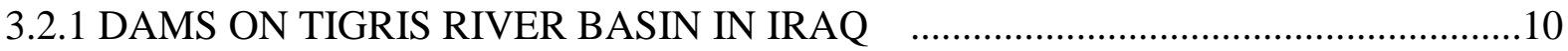

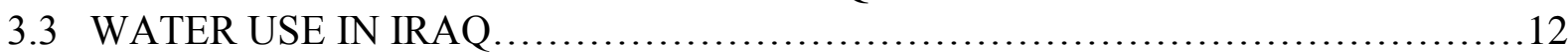

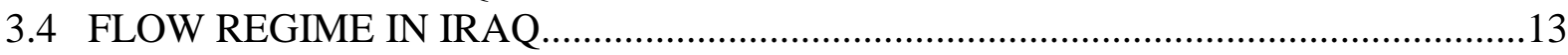

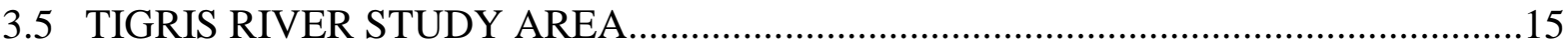

4.0 WATER QUALITY IN IRAQ …..................................................................................

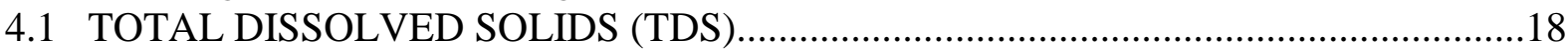

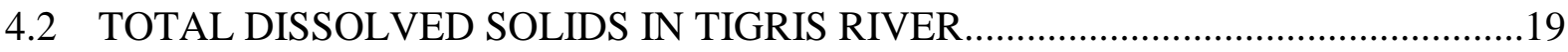

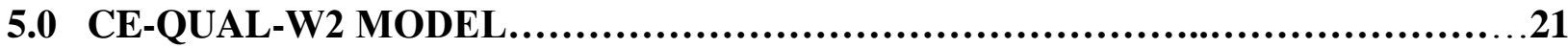

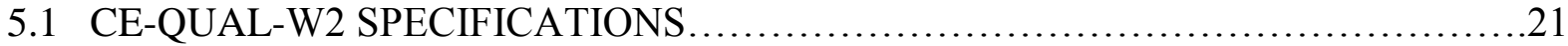

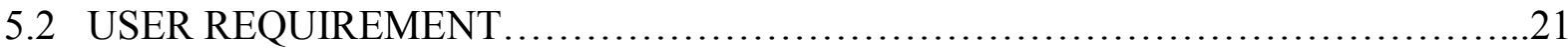

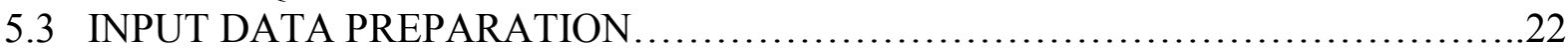

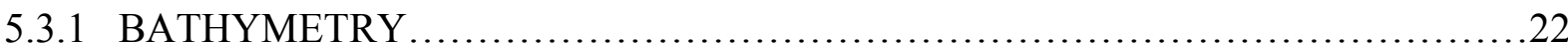

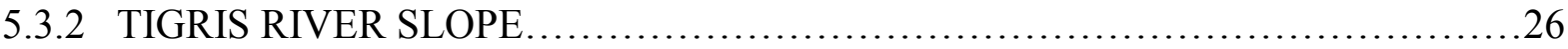

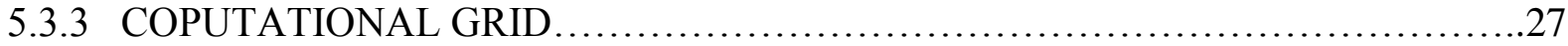

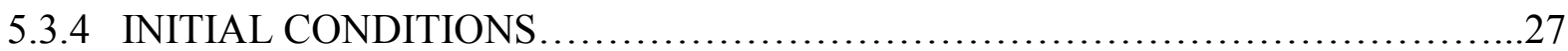

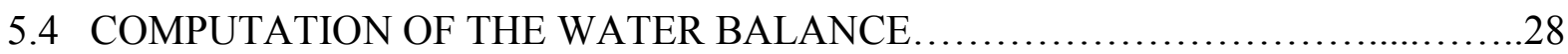

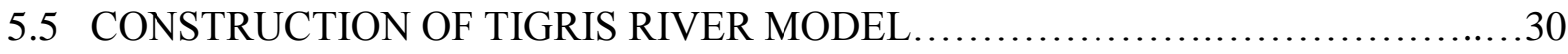

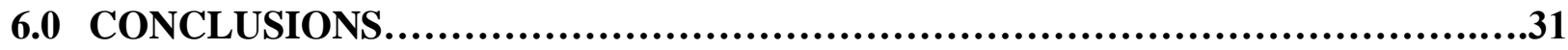

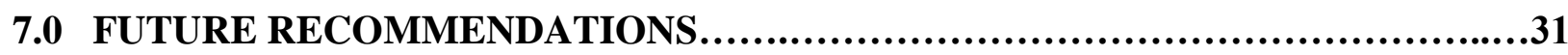

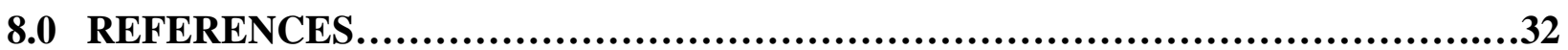




\section{LIST OF TABLES}

Table 1. Table 1. Drainage area of the Euphrates River basin ............................6

Table 2: Lower tributaries of the Tigris River....................................

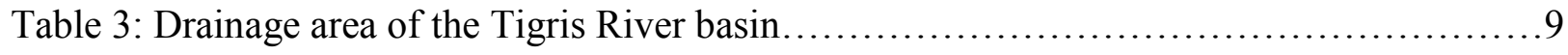

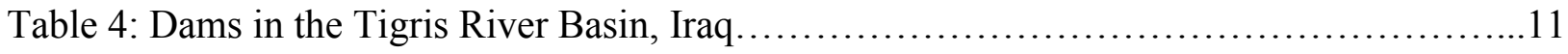




\section{LIST OF FIGURES}

Figure 1: The Middle East map ..................................................... 1

Figure 2: The official map of Iraq with Tigris and Euphrates Rivers .........................2

Figure 3: Sketch of the Mesopotamia river system .........................................5

Figure 4: Sources of water for the Tigris and Euphrates Rivers.............................5

Figure 5: Salinity in the Euphrates within Iraq prior to 1973 and after $1980 \ldots \ldots \ldots \ldots \ldots \ldots \ldots . \ldots . \ldots . \ldots . \ldots$

Figure 6: Contribution of tributaries to Tigris River.................................... 8

Figure 7: Average monthly recorded discharges of Tigris River at Sarai Baghdad station for the

period 1960-2012. (Data source until 2007.....................................

Figure 8: Drainage Basins for Tigris and Euphrates Rivers.............................. 10

Figure 9: Dams in Tigris and Euphrates basins within Iraq...............................11

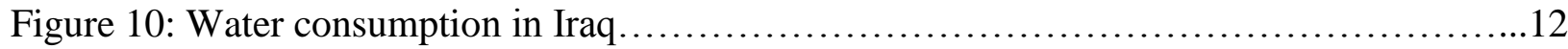

Figure 11: Water supply Vs. water demand in Tigris and Euphrates Rivers .....................12

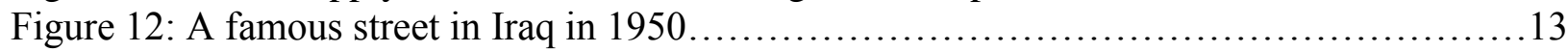

Figure 13: Schematic diagram of the hydrological scheme in Iraq.........................14

Figure 14: Tigris River study area from Mosul Dam to Kut Barrage.........................15

Figure 15: Study area with waterbodies and branches................................... 16

Figure 16: Samarra Barrage with two channels...................................... 17

Figure 17: Diversion of water from Tigris River to Tharthar depression.................... 17

Figure 18: Total dissolved solids TDS in Tigris River..................................19

Figure 19: Total dissolved solids concentrations at Samarra Barrage and at the outlet of the

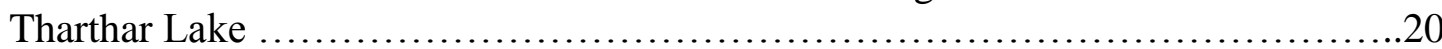

Figure 20: Tigris River Bathymetry example ......................................22

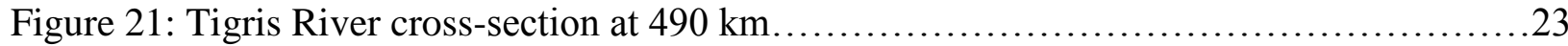

Figure 22: Gaps between Projected points on Tigris River..............................24

Figure 23: Segment \# 3 with ten active layers constructed by W2 model.....................25

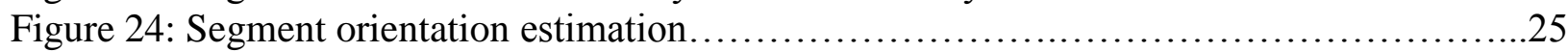

Figure 25: Tigris River study area constructed by W2 model............................26

Figure 26: Bottom Elevation of Tigris River from Mosul Dam to Kut Barrage.................26

Figure 27: A computational grid example.............................................

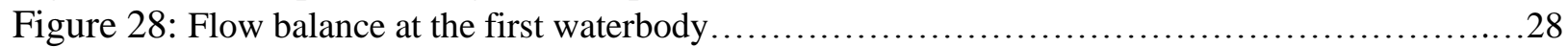

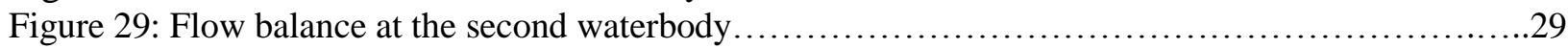

Figure 30: CE-QUAL-W2 window of Tigris River model............................. 30 


\subsection{INTRODUCTION}

Water is the most precious gift of nature, the most crucial for sustaining life and is required in almost all human being activities. Drinking, municipal use, irrigation, industries, power generation, navigation, and recreation. Iraq is located in the Middle East (figure 1) and covers an area of 433,970 square kilometers populated by about 35 million inhabitants. The Tigris River is one of the largest rivers in Iraq and is considered the main source of drinking water for Baghdad city, which is the largest city in the country and the second largest city in the Arab world with a population estimated by 7.5 million (Burnham et al., 2006; Al-Janabi et al., 2001). The Tigris is $1850 \mathrm{~km}$ long, rising in the Taurus Mountains of eastern Turkey about $25 \mathrm{~km}$ southeast of the city of Elazig and about $30 \mathrm{~km}$ from the headwaters of the Euphrates. As many structures have been built along the Tigris, especially in Turkey, the river discharge is changing continuously and therefore the elevation of the water in the river also changes and as a result, intakes of water treatment plants and power generation plants are affected (Al-Obaidy, 1996; Al-Jubori, 1998).

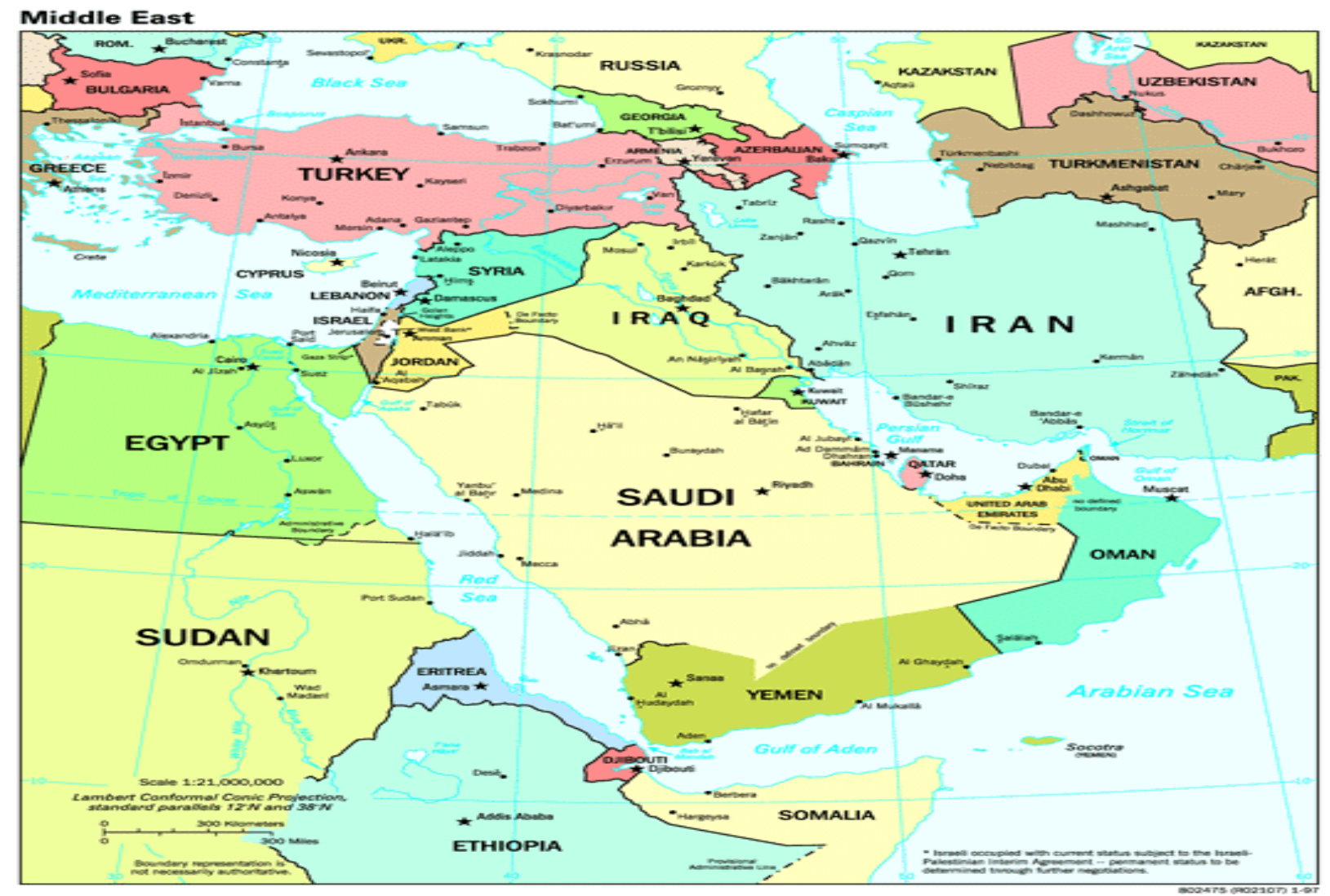

Figure 1: The Middle East map (Univ. of Texas 2003). 
Figure 2 shows the official map of the republic of Iraq and indicates the two big rivers, Tigris, eastern member, and Euphrates, western member, as they enter Iraq from the border to their mouth where they form Shatt Al-Arab River, 200 km, in Qurna city.

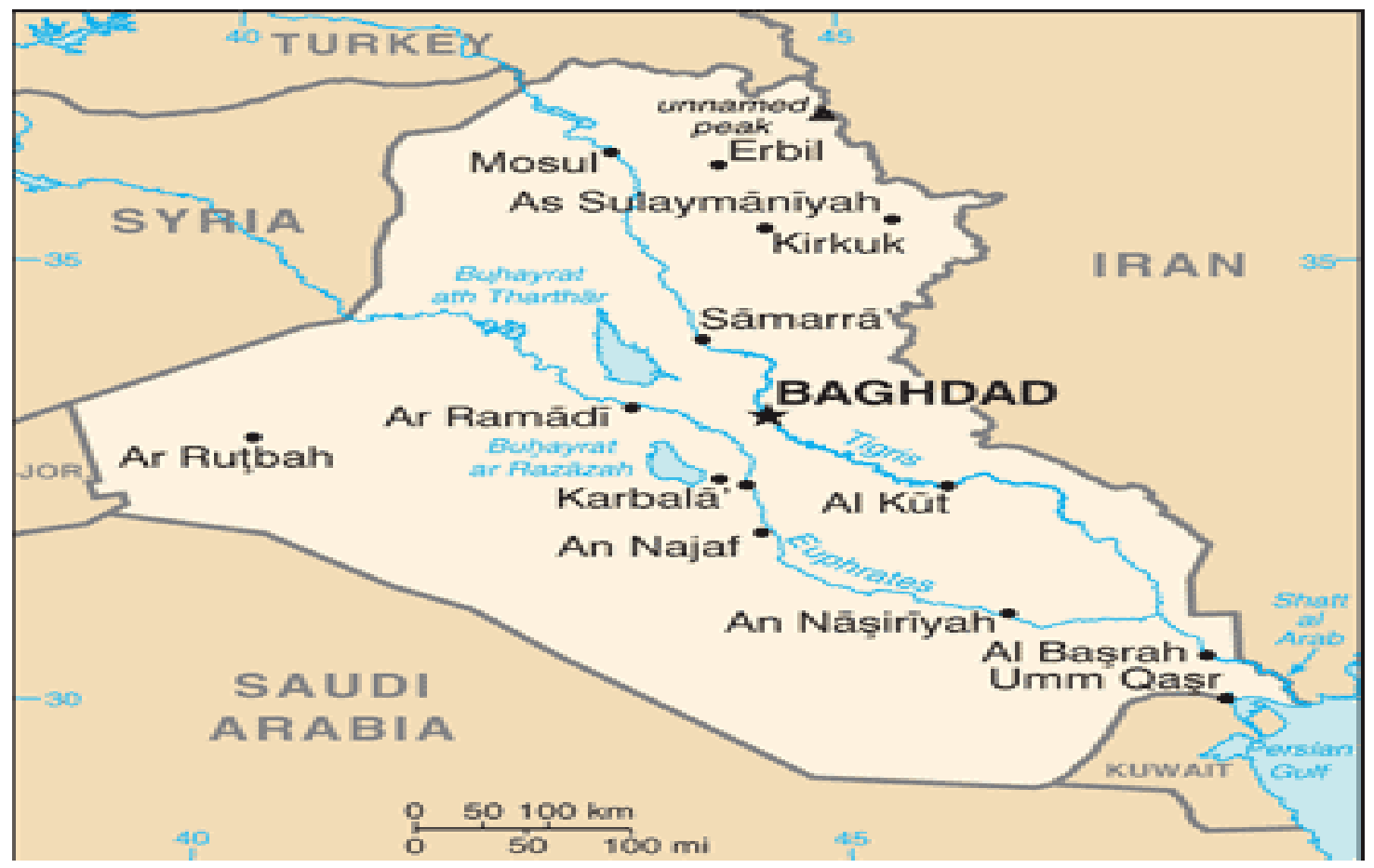

Figure 2: The official map of Iraq with Tigris and Euphrates Rivers (Univ. of Texas 2014).

Several cities have been built on the banks of Tigris River since the dawn of civilization. Among these cities are Baghdad, Mosul, Samarra, and Kut. Parts of these cities were inundated by the spring floods of the river in 1954, 1971, and 1988 (Ali et al. 2012). Many studies conducted on the Tigris River, but were all concentrated on limited area. Therefore, the present study aims to imply a water quality model over a long study area of $880 \mathrm{~km}$. 


\subsection{Literature Review}

Kadhem (2013) has compared water quality data of Tigris River using geographic information system (GIS). In his study, the analytical results show high concentration of total dissolved solid (TDS), electric conductivity (EC), total hardness, Chloride (Cl), and Iron (Fe). The World Health Organization (WHO) and Iraqi water standards are used in the study to compare water quality concentrations.

Ali et al., (2012) use surveyed data of the bed of Tigris River to predict the maximum flood capacity for the river using one dimensional hydraulic model for steady flow "HEC-RAS" In their study, calibration of the model was carried out using field measurements for water level. The model showed a significant predicted reduction in the current river capacity below that which the river had carried during the floods of 1971 and 1988.

Al-Anbari et al., (2006) have studied the hydraulic geometry for a stretch of $202.5 \mathrm{~km}$ on Tigris River from Mosul at km 177.5 in the north, downstream to km 380 near Bejee at the Al-Fathaa Bridge using Leopold's method at maximum, minimum, and average discharges. The results show that there is different hydraulic geometry characteristics along the river reach with high width to depth ratio.

According to Al-Marsoumi et al., (2006), the ionic concentrations of both Tigris and Euphrates Rivers increase downstream with a significant increase of the Euphrates due to the longer river coarse beside the extent and the diversity of Euphrates River compared with that of the Tigris. As total hardness was measured in the study, the Euphrates could be divided into two groups from upstream to downstream as hard to very hard respectively, while Tigris water is considered hard.

In their study, Rahi and Halihan (2010) examined water salinity of Euphrates River within Iraq. Water salinity expressed by total dissolved solids (TDS) has more than doubled compared to that of 1973. According to their study, they illustrate the increasing in the water salinity to the decreased flow that is entering Iraq, diverted flow from Tharthar Lake, and irrigation return flow. To mitigate salinity concentrations in the Euphrates, an environmental flow rate of $178 \mathrm{~m}^{3} / \mathrm{s}$ is proposed as the minimum discharge that must be flowing into Iraq. 
Saad and Antoine (1978) have investigated water quality in the 630km stretch of the lower Tigris. Air and average water temperatures were recorded in January. According to $\mathrm{pH}$ measurements, it is found that $\mathrm{pH}$ values are generally high in July and October and is mainly due to the abundance of phytoplankton. Adversely, dissolved oxygen values were found to be high in January and April.

Altinbilek (2004) has discussed issues related to the development and management of the Euphrates-Tigris basin. In this study, historical perspectives on water conflict, geography, water and land resources development in three riparian countries namely; Iraq, turkey, and Syria are examined. Altinbilek has concluded that water conflict in the Euphrates-Tigris basin requires a hydro-political approach that covers legal, political, technical and economic aspects.

Alobaidy et al., (2010) apply water quality index in Dokan Lake, Kurdistan region. Ten water quality parameters $(\mathrm{pH}, \mathrm{DO}$, Turbidity, conductivity, hardness, alkalinity, sodium, BOD, nitrate and nitrite) are used in this study. Based on the importance of each parameter for aquatic life, a relative weight assigned to each parameter ranged from 1 to 4 . The results indicated that water quality of Dokan Lake declined from good in the years 1978, 1979, 1980, 1999, 2000 and 2008 to poor in 2009. It is suggested to monitor Dokan Lake more regularly by implementation of WQI as a very helpful tool that enables the public and decision makers to evaluate water quality of lakes in Iraq. 


\subsection{Water Resources in Iraq}

The Rivers Tigris and Euphrates form the main water sources of Iraq. Both these rivers originate in the highlands of Turkey and share their physical, climatic, hydrologic and geomorphologic characteristics (figure 3). They join together in the south forming what is referred to as the Shat Al-Arab, which drains towards the Persian Gulf. It is worth to know that both rivers have different flow patterns and Tigris River carries much water than Euphrates River.

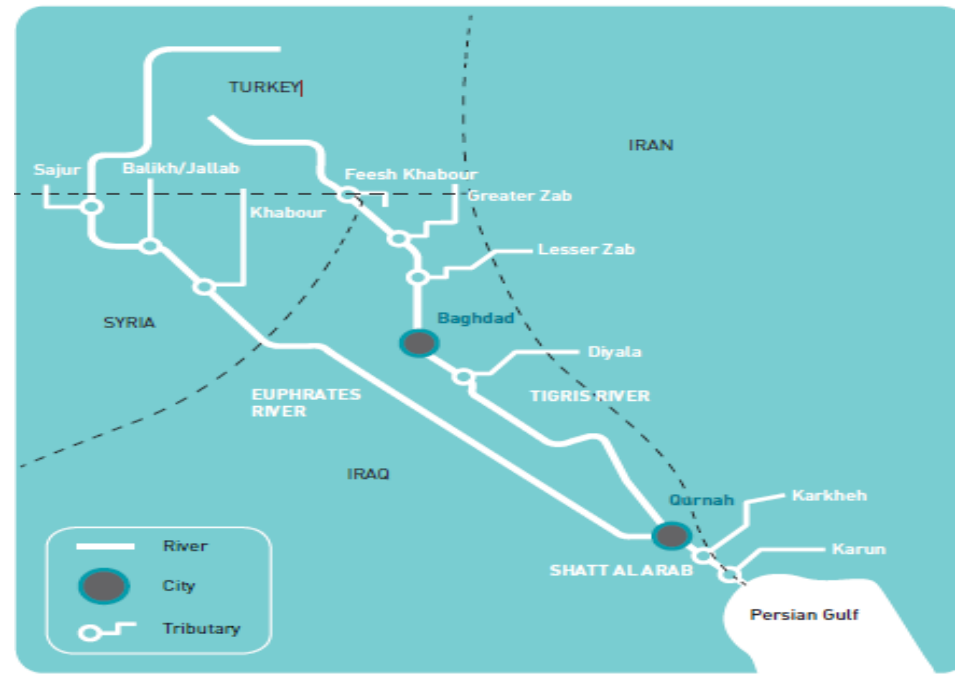

Figure 3: Sketch of the Mesopotamia river system.

Source: Compiled by (UN- ESCWA and BGR, 2013).

Most of the water from both Tigris and Euphrates Rivers comes from Turkey (71\%) followed by Iran (6.9\%) and Syria (4\%). The reminder is only $8 \%$ which is coming from internal sources (figure 3) (Al-Ansari, 2013).

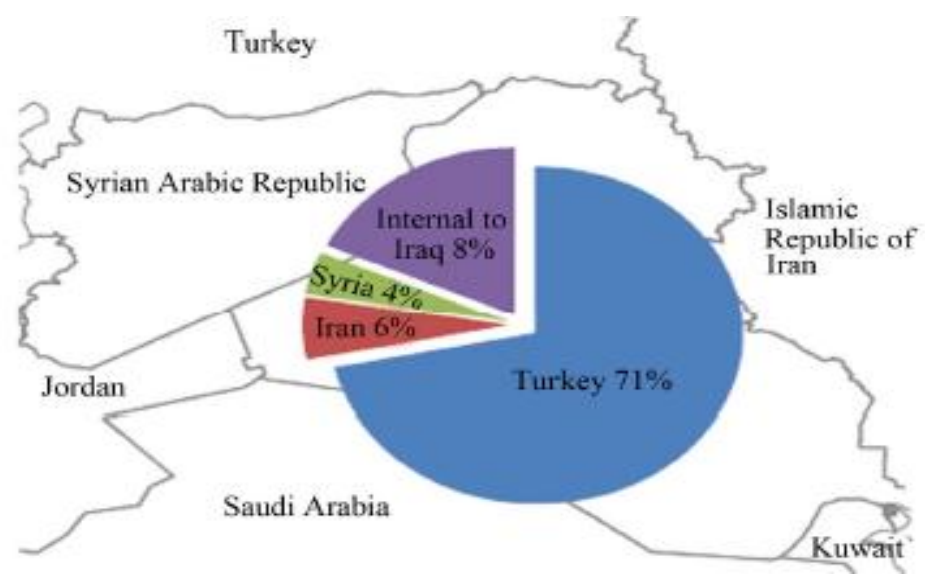

Figure 4: Sources of water for the Tigris and Euphrates Rivers (Source: MWR, 2010). 


\subsection{Euphrates River}

The Euphrates River is $2781 \mathrm{~km}$ long and rises from the south eastern parts of Turkey. It does not have any tributary inside Iraq, except small seasonal wadies from the west The River's drainage area is shared by four riparian countries (Iraq 41\%, Turkey 28\%, Syria 17\%, and Saudi Arabia 14\%). The drainage area of the Euphrates River basin is listed in table 1 (Al-Ansari, 2013).

Table 1. Drainage area of the Euphrates River basin (Al-Ansari and Knutsson, 2011).

\begin{tabular}{|l|l|l|}
\hline Country & Catchment Area $\left.\mathbf{( k m}^{2}\right)$ & Catchment Area (\%) \\
\hline Iraq & 177,000 & 39.9 \\
\hline Turkey & 125,000 & 28.2 \\
\hline Syria & 76,000 & 17.1 \\
\hline Saudi Arabia & 66,000 & 14.9 \\
\hline Total & 444,000 & 100 \\
\hline
\end{tabular}

The Euphrates River serves seven provinces and the western portion of Baghdad. As the Euphrates receives some water from Tharthar Lake, its water becomes more saline since Tharthar Lake has a high concentration of total dissolved solids (TDS). Historically, the Euphrates waters had low salinity. In Turkey, the TDS was 261 ppm which is suitable for irrigation while TDS values in Iraq reach as high as 3500ppm. Figure 5 compares salinity concentrations of the Euphrates within Iraq for the years before 1973 and the years after 1980 (Rahi and Halihan, 2009). 


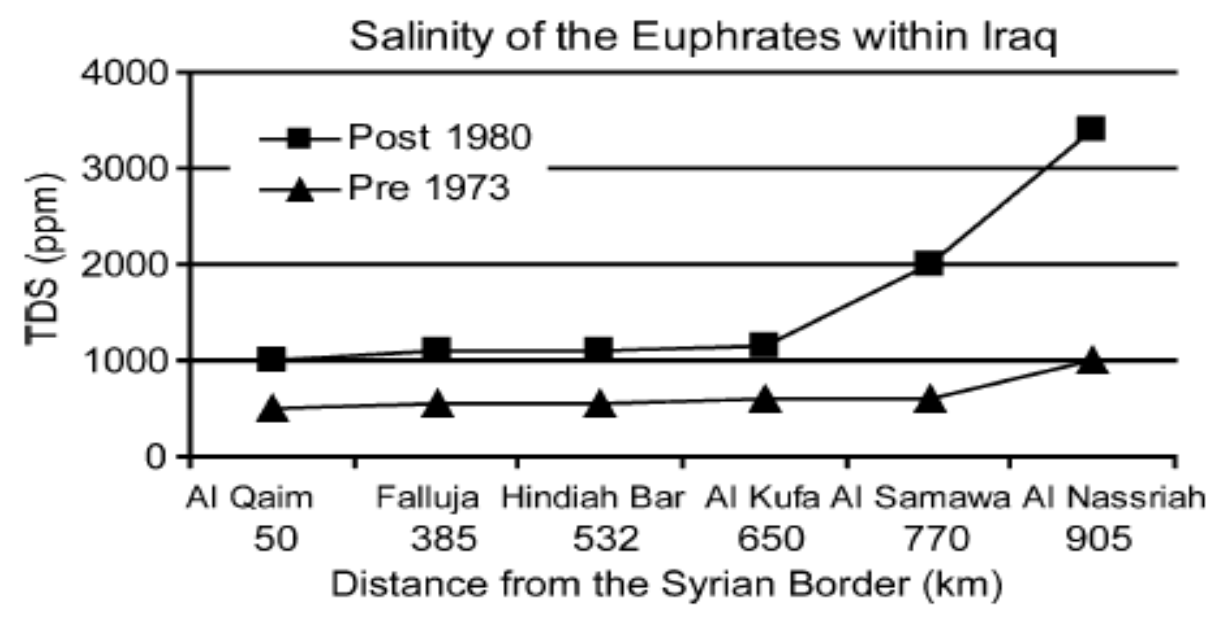

Figure 5: Salinity in the Euphrates within Iraq prior to 1973 and after 1980 (Rahi and Halihan 2009).

\subsection{Tigris River}

Tigris River is one of the largest rivers in the Middle East, starching for over $1850 \mathrm{~km}$, of which $1418 \mathrm{~km}$ are within Iraq. Tigris River is rising from Taunus Mountains of Eastern Turkey and flows for about $400 \mathrm{~km}$ through Turkey before entering Iraq. Tigris River has five tributaries inside Iraq; they are from north to south: Khaboor River which is located near turkey-Iraqi border (Tusan), Upper Zab at about $50 \mathrm{~km}$ downstream Mosul city, Lower Zab at about $220 \mathrm{~km}$ upstream Baghdad city, Adhaim River $50 \mathrm{~km}$ upstream Baghdad city, and Diyala River at $10 \mathrm{~km}$ downstream Baghdad city (Al-Samak et al., 1985) (fig 6 and table 2). It drains an area of $473,103 \mathrm{~km}^{2}$ which is shared by Turkey, Syria, Iran and Iraq (table 3). At Qurna city, south of Iraq, Tigris meets Euphrates to for Shatt Al-Arab River which eventually drains into the Gulf.

Table 2: Lower tributaries of the Tigris River (ESCWA-BGR, 2013)

\begin{tabular}{|c|l|}
\hline Tributary & \multicolumn{1}{c|}{ Description } \\
\hline Feesh Khabour & $\begin{array}{l}\text { This tributary is shared between Iraq and Turkey. It rises in Sirnak, Turkey, } \\
\text { and flows through Zakho, Iraq, before its confluence with the Tigris at the } \\
\text { Iraqi-Turkish border. The Feesh Khabour delineates the international border } \\
\text { between Iraq and Turkey. Its mean annual flow volume at the confluence with } \\
\text { the Tigris is approximately 2 BCM. }\end{array}$ \\
\hline Greater Zab & $\begin{array}{l}\text { This river, which is shared by Iraq and Turkey, originates in Turkey and is the } \\
\text { largest Tigris tributary. It supplies the Tigris River with an average annual flow } \\
\text { volume of 12.7 BCM. }\end{array}$ \\
\hline Lesser Zab & $\begin{array}{l}\text { The Lesser Zab is shared by Iran and Iraq. It originates in Iran, not far from the } \\
\text { Iraqi border. The average annual flow volume of the Lesser Zab is about 7.8 } \\
\text { BCM, contributing an average of 249 m3/s to the Tigris. }\end{array}$ \\
\hline
\end{tabular}




\begin{tabular}{|c|l|}
\hline Adhaim & $\begin{array}{l}\text { While not a shared tributary in itself, the Adhaim is an intermittent stream that } \\
\text { drains an area of about } 13,000 \mathrm{~km} 2 \text { in Iraq. The river generates about } 0.79 \\
\text { BCM annually at its confluence with the Tigris and is subject to flash flooding. }\end{array}$ \\
\hline Diyala & $\begin{array}{l}\text { Shared by Iran and Iraq, this tributary also forms the border between the two } \\
\text { countries for about } 30 \mathrm{~km} \text {. The Diyala has a mean annual flow volume of } 4.6 \\
\text { BCM. }\end{array}$ \\
\hline
\end{tabular}

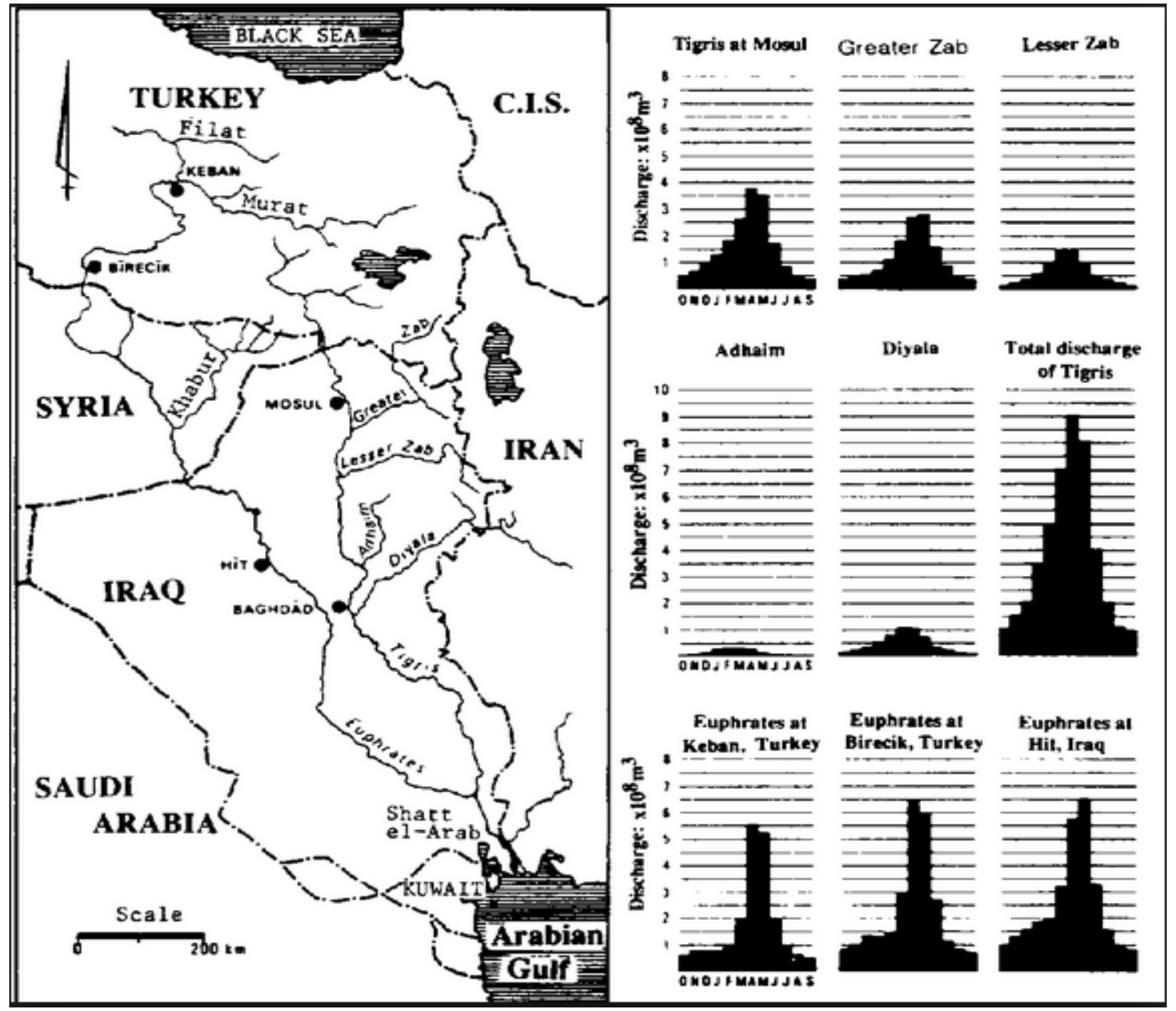

Figure 6: Contribution of tributaries to Tigris River (Beaumont et al., 1988). 
Table 3: Drainage area of the Tigris River basin (Al-Ansari and Knutsson, 2011).

\begin{tabular}{|l|l|l|}
\hline Country & $\begin{array}{l}\text { Catchment Area } \\
\left(\mathbf{k m}^{\mathbf{2}}\right)\end{array}$ & Catchment Area (\%) \\
\hline Iraq & 253,000 & 58 \\
\hline Turkey & 57,614 & 12.2 \\
\hline Syria & 834 & 0.2 \\
\hline Iran & 140180 & 29.6 \\
\hline Total & 473103 & 100 \\
\hline
\end{tabular}

Tigris River serves more provinces than Euphrates River. Major cities from upstream to downstream: Mosul, Samarra, Baghdad, Diyalah, and Kut are located on the main stream of the Tigris. Tigris River mean discharge at Mosul city prior to 1984 was $701 \mathrm{~m}^{3} / \mathrm{s}$ and dropped to596 $\mathrm{m}^{3} / \mathrm{s}$ afterward. This implies a 15\% decrease of the river discharge (Figure 7) (Al-Ansari and Knutsson, 2011). The total drainage area for both Tigris and Euphrates basins is indicated in figure 8 .

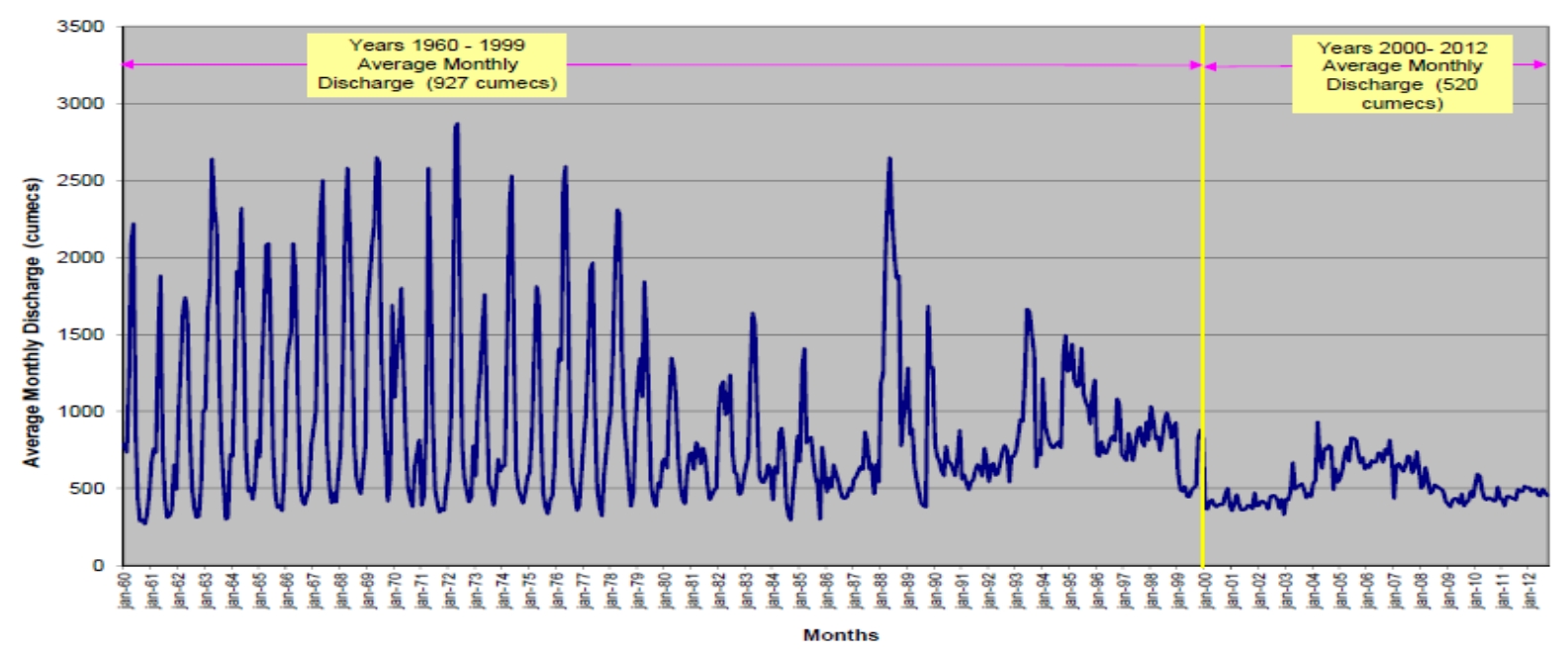

Figure 7: Average monthly recorded discharges of Tigris River at Sarai Baghdad station for the period 1960-2012. (Data source until 2007 from (Al-Shahrabaly, 2008)). 


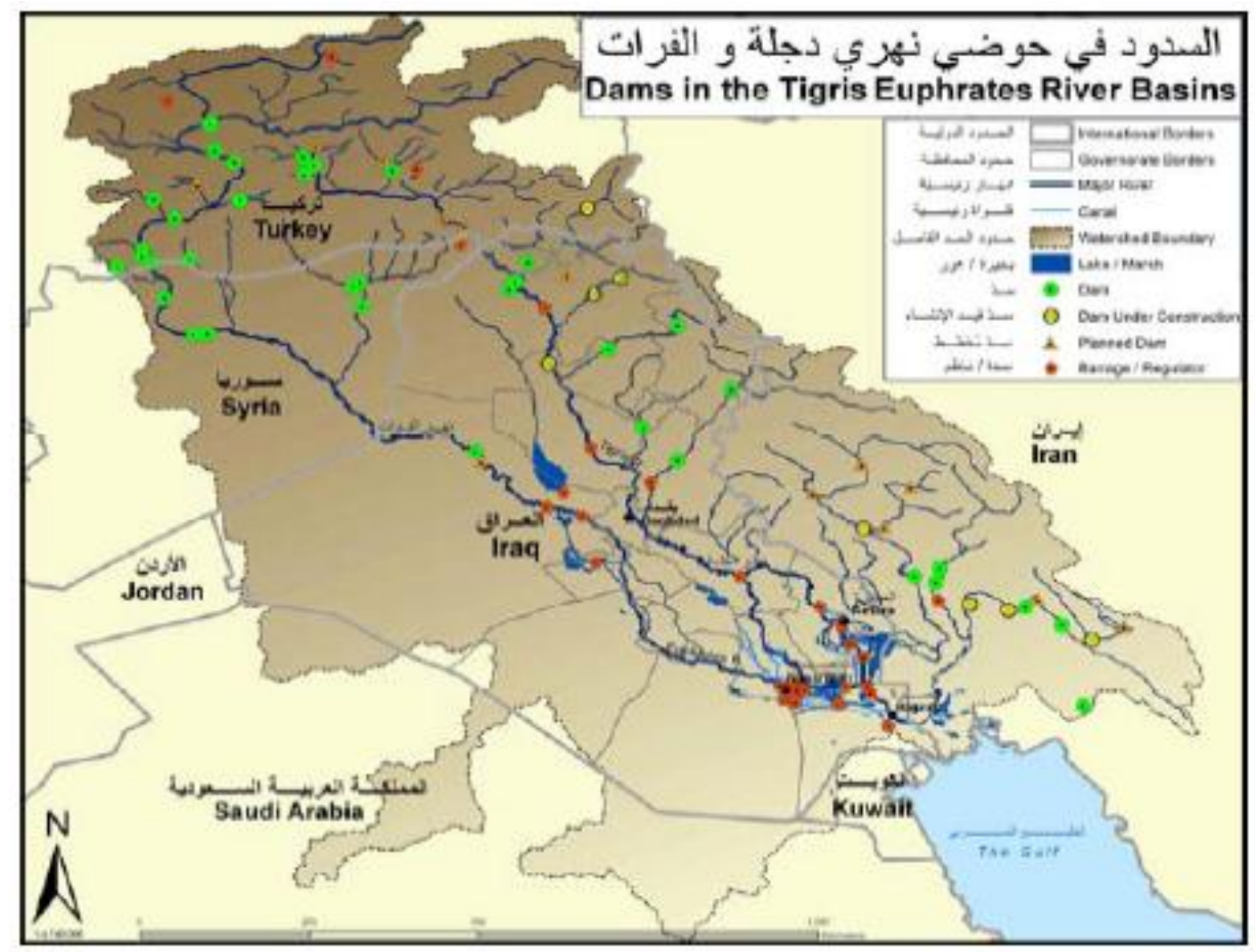

Figure 8: Drainage Basins for Tigris and Euphrates Rivers (Univ. of Victoria, 2010).

\subsubsection{Dams on Tigris River Basin in Iraq}

The Tigris is heavily dammed in Iraq and Turkey to provide water for irrigating of the arid regions. Turkey developed the Greater Anatolia Project (GAP), it consist of 22 dams. Some of them are in operation. Therefore, water is highly restricted by Turkey. Ataturk dam which is located about $80 \mathrm{~km}$ upstream from the Turkish-Syrian border is the key project within GAP. Ataturk dam has a capacity of about 48.7 BCM (Beaumont, 1996). As the water is highly regulated by Turkey and due to the huge increase of water demand, the Iraqi Government realized that the process of building dams along both rivers and all tributaries should be considered seriously. A series of dams have been built and some have been stopped due to the Gulf war in 1990 (table 4 and figure 9). 
Table 4: Dams in the Tigris River Basin, Iraq (web reference 2).

\begin{tabular}{|l|l|l|l|l|l|l|}
\hline Name & City & River & Year & $\begin{array}{l}\text { Height } \\
(\mathrm{m})\end{array}$ & Capacity $\left(\mathrm{M} \mathrm{m}^{3}\right)$ & Main Use \\
\hline Mosul & Mosul & Tigris & 1983 & 131 & 12,500 & I \\
\hline Dokan & Sulaymaniyah & Lesser Zab & 1961 & 116 & 6,800 & I \\
\hline Dibis & Dibis, Kirkuk & Lesser Zab & 1965 & 15 & 3,000 & I \\
\hline Samarra & Samarra & Tigris & 1954 & - & 72,800 & F \\
\hline Adhaim & Adhaim & Adhaim River & 1999 & - & - & - \\
\hline Himrin & Ba'qubah & Diyalah River & 1980 & 40 & 4,000 & I \\
\hline Derbendi Khan & Ba'qubah & Diyalah River & 1962 & 128 & 3,000 & I \\
\hline
\end{tabular}

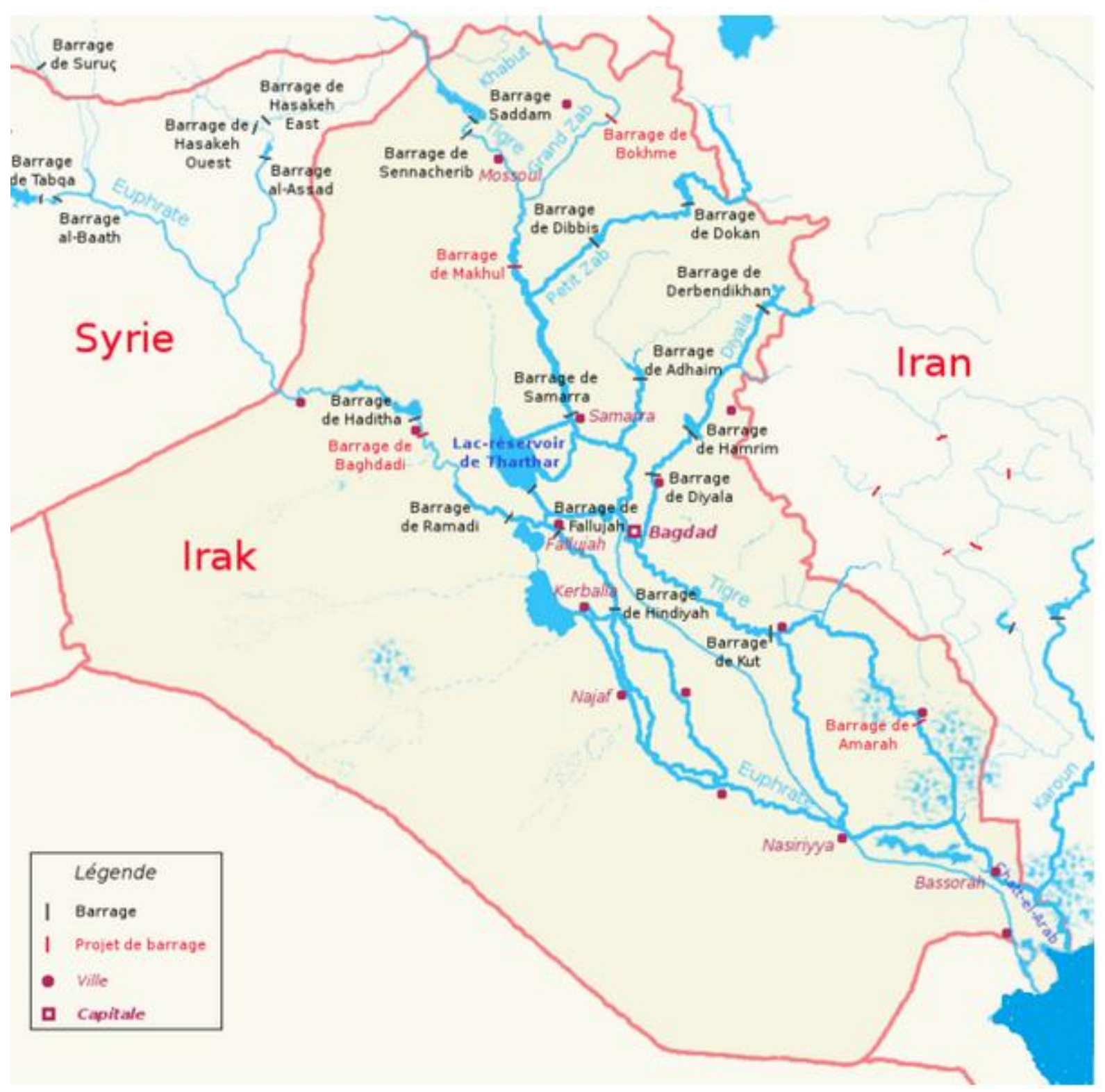

Figure 9: Dams in Tigris and Euphrates basins within Iraq (Gatte and Kadhim 2012). 
It can be clearly seen from figure 9 that Tigris River and its tributaries have more structures than Euphrates River since Tigris has more water and is expected to flood during the flood season. Although Upper Zab is one of the major tributaries and significantly contributes water in to the Tigris, no dams have been built up to date on this tributary. A proposed dam, Bekhme, is under construction at the upstream of the Upper Zab to control the flow.

\subsection{Water Use in Iraq}

Compared to the industrial and domestic water demand, all riparian countries consider the agriculture sector is the most demanding in terms of water withdrawal (figures 10 and 11). Irrigation water system is a crucial sector in Iraq since all wades in the Tigris and Euphrates basins are in dire need to irrigation water system, while the agricultural areas in the north and the north east of Iraq are recognized for the potential irrigation due to the heavy rain which is sufficient to cultivate winter crops.

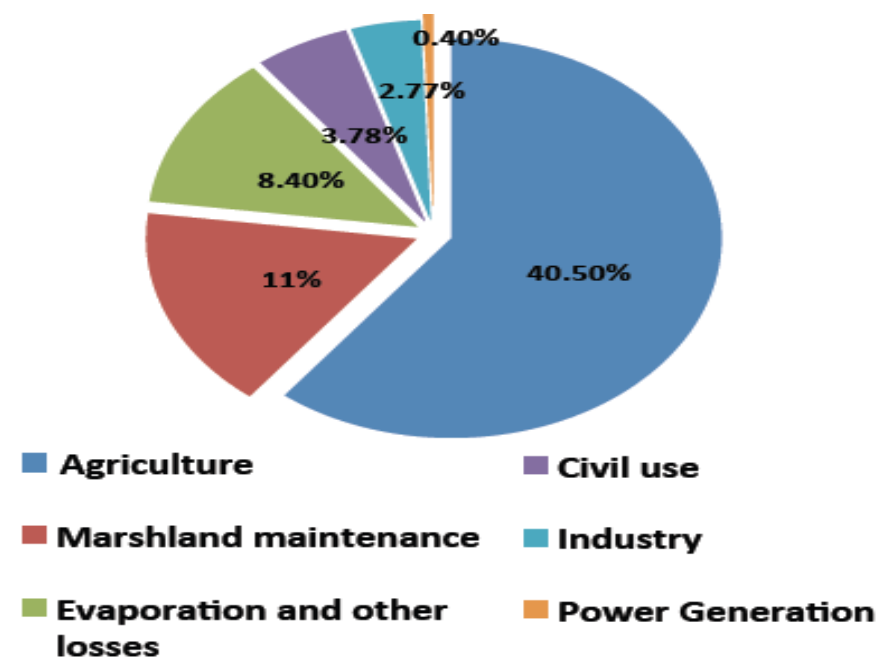

Figure 10: Water consumption in Iraq (Water in Iraq Factsheet, 2013).
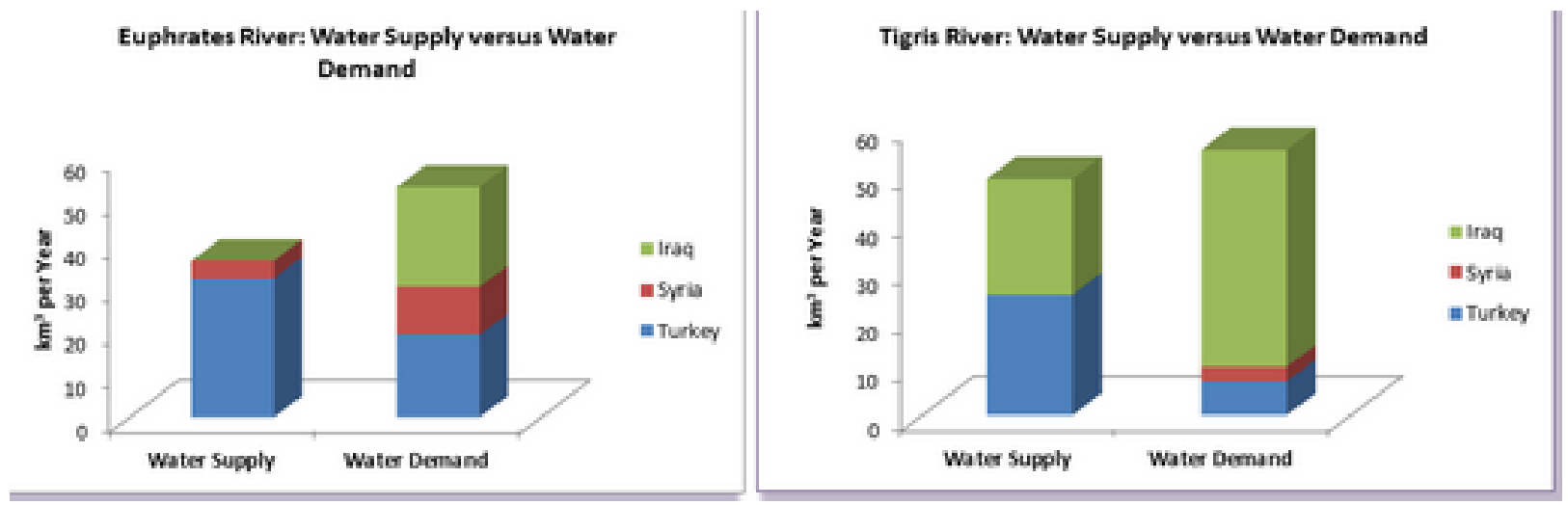

Figure 11: Water supply Vs. water demand in Tigris and Euphrates Rivers (Water Deficit 2003). 


\subsection{Flow Regime in Iraq}

As mentioned before, Tigris River has much water than Euphrates River. Therefore, Baghdad city is occasionally exposed to flooding due to high flows in the Tigris River. The last big flood happened in 1950 (figure 12). Therefore, Iraqi Government started to construct series of dams and projects to control the flow and to prevent major cities from flooding.

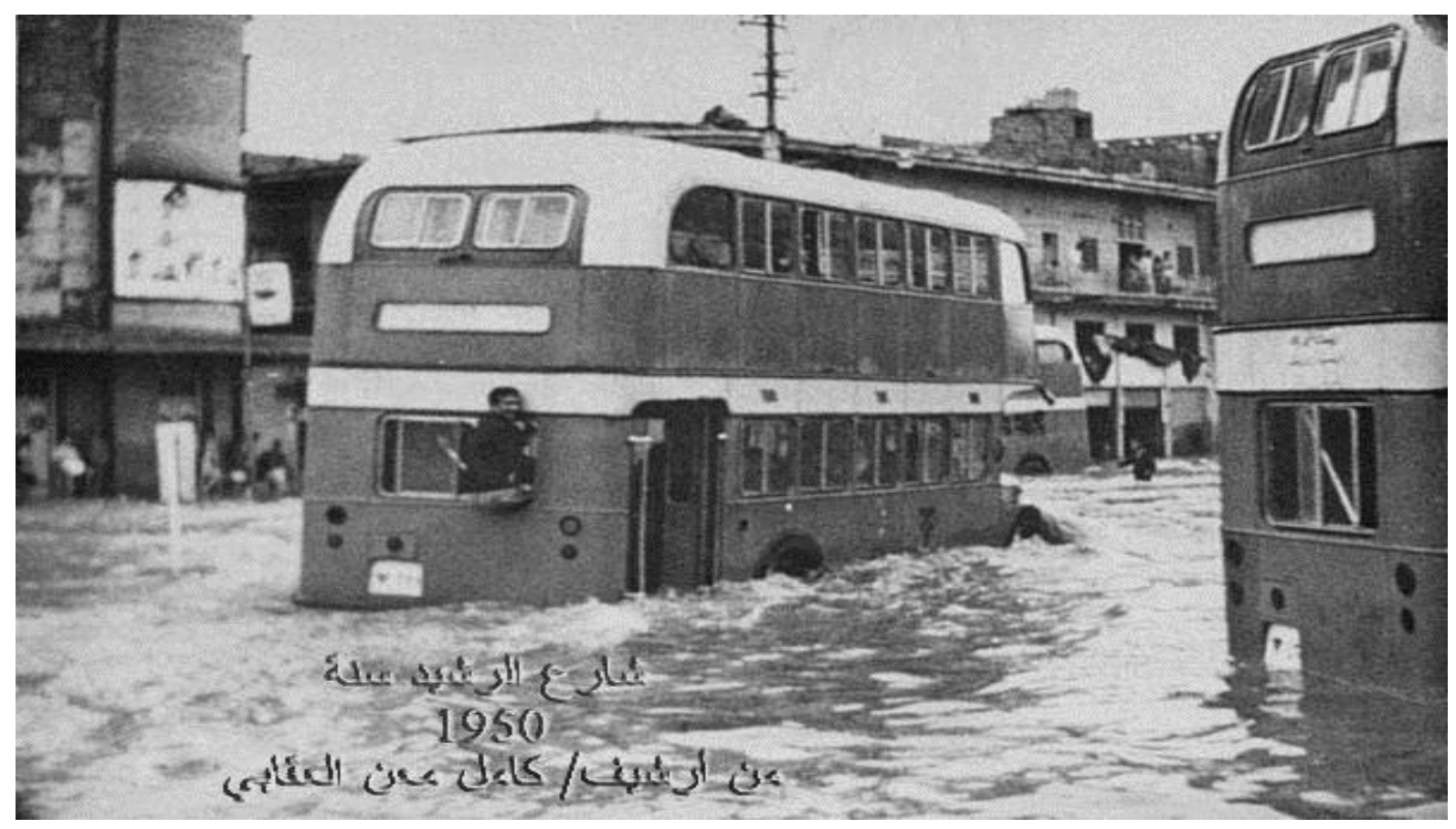

Figure 12: A famous street in Iraq in 1950 (Source: Iraq the lasting love, web).

Water diversion from the Tigris is one solution to control flood in Baghdad, the capital of Iraq, and other downstream cities. Tharthar Lake, figure 2, is the biggest lake in Iraq and is located about $65 \mathrm{~km}$ to the north west of Baghdad city. The main purpose of this lake is flood control and water storage for irrigation. All dams, lakes, depressions, barrages, and regulators in Iraq are shown in figure 13. Compared with Euphrates River, it can be clearly seen that more dams have been constructed along Tigris River basin due to large water quantity. 


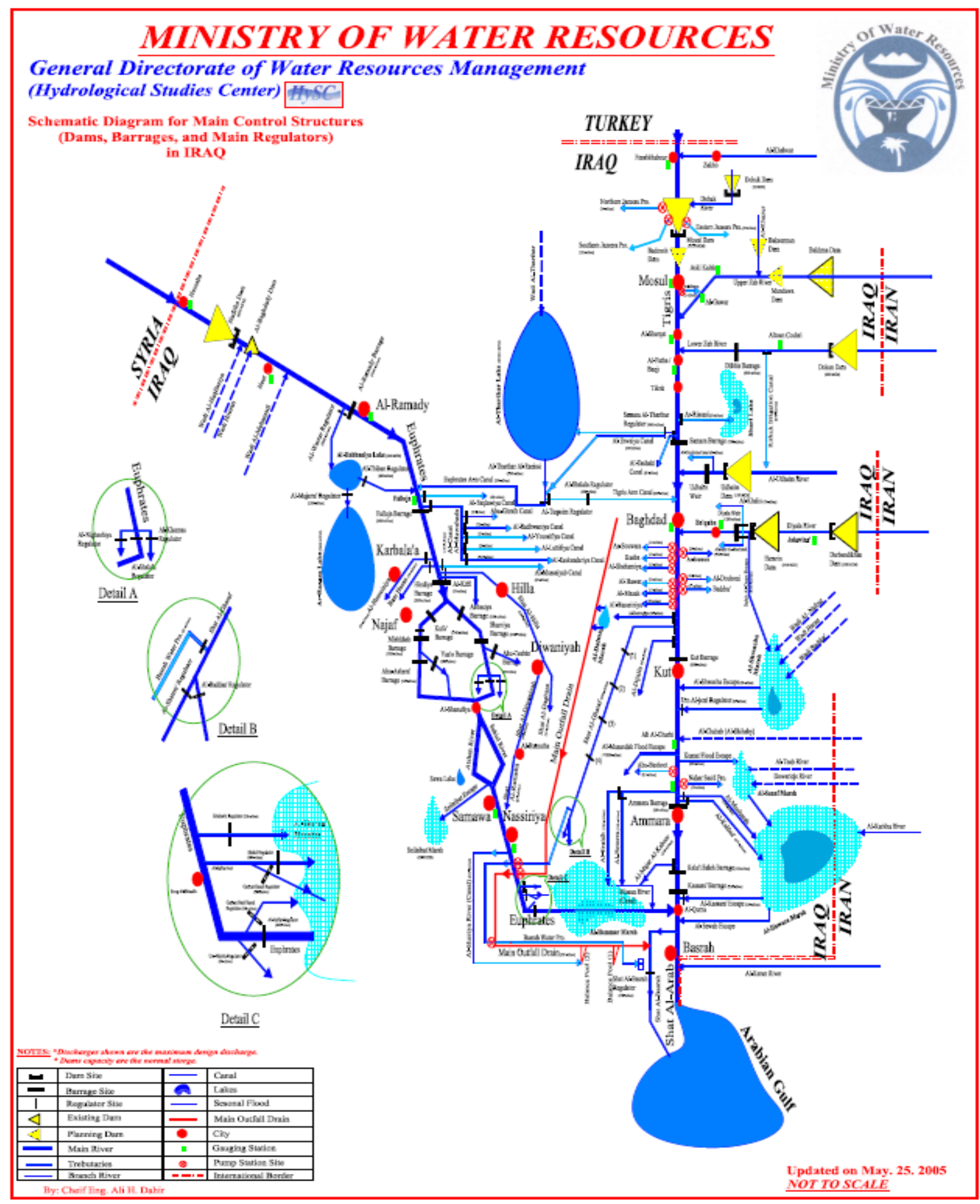

Figure 13: Schematic diagram of the hydrological scheme in Iraq (Source: MWR, 2005) 


\subsection{Tigris River Study Area}

The study area stretch of $880 \mathrm{~km}$ has been selected on the Tigris River from Mosul Dam to Kut Barrage (figure 14). Google Earth is used to visualize the study area. Many major cities such as Mosul, Tikrit, Samarra, Baghdad, Diyalah, and Kut are located along the main channel of Tigris River. Mosul Dam, Samarra Barrage, and Kut Barrage are crucial structures located on the Tigris River that control the flow. Along the study area, three major tributaries join the Tigris from upstream to downstream namely; Upper Zab, Lower Zab, and Diyalah River, while Ahdaim River is a minor tributary with very low water contribution to Tigris River. Dams have been built along all these tributaries except Upper Zab which has no Dams been built up to date.

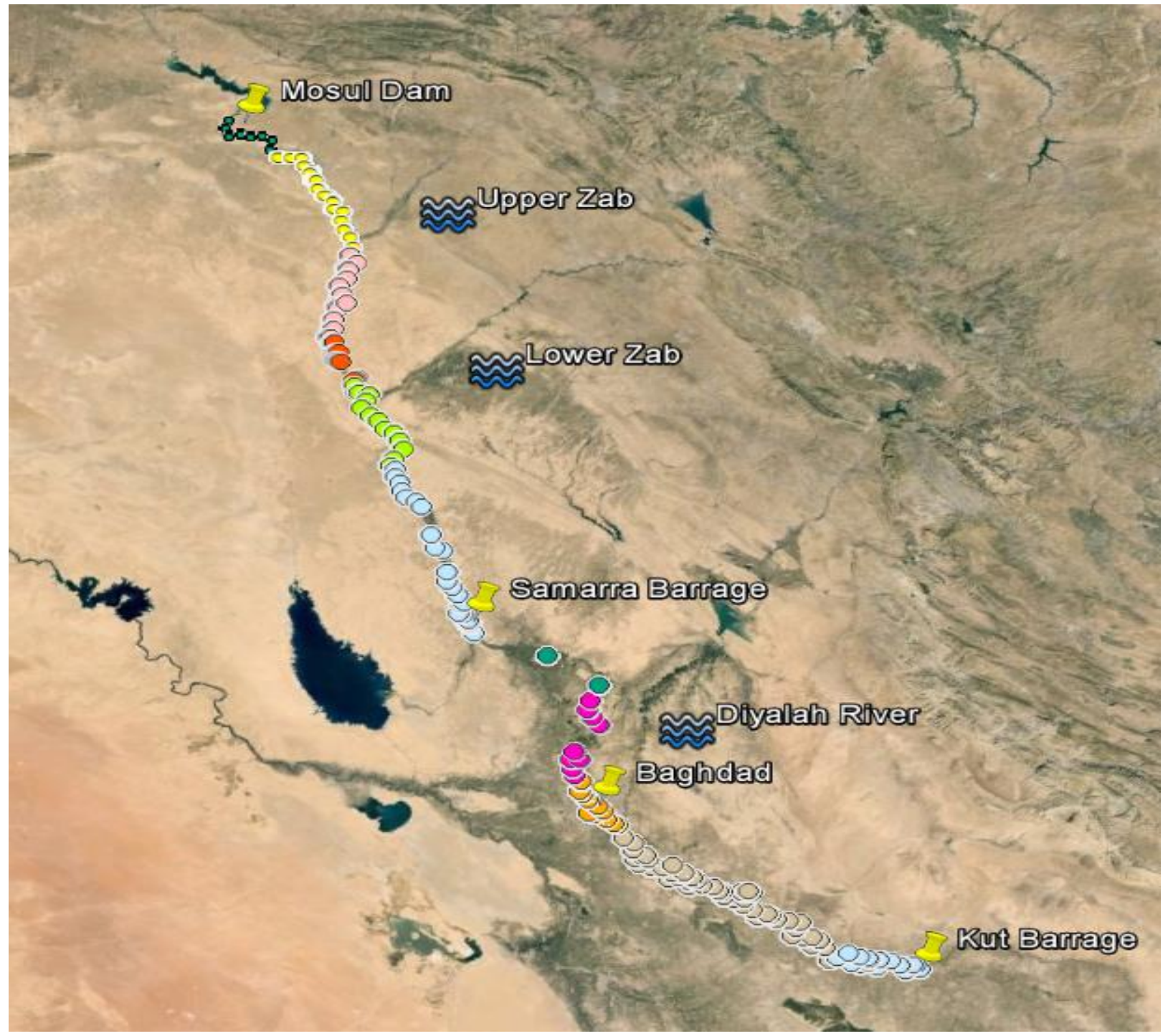

Figure 14: Tigris River study area from Mosul Dam to Kut Barrage (Google Earth). 
The study area is divided into two waterbodies (figure 15), each waterbody has two branches and ends with a structure. The first waterbody $(375 \mathrm{~km})$ starts from Mosul Dam down to Samarra Barrage. It has two branches from Mosul Dam to Tikrit city $(335 \mathrm{~km})$ and from Tikrit city to Samarra Barrage $(40 \mathrm{~km})$ respectively. The second waterbody $(505 \mathrm{~km})$ starts from Samarra Barrage to Kut Barrage. It has two branches from Samarra Barrage to $50 \mathrm{~km}$ downstream Baghdad city $(260 \mathrm{~km})$ and from that to Kut Barrage $(245 \mathrm{~km})$ respectively.

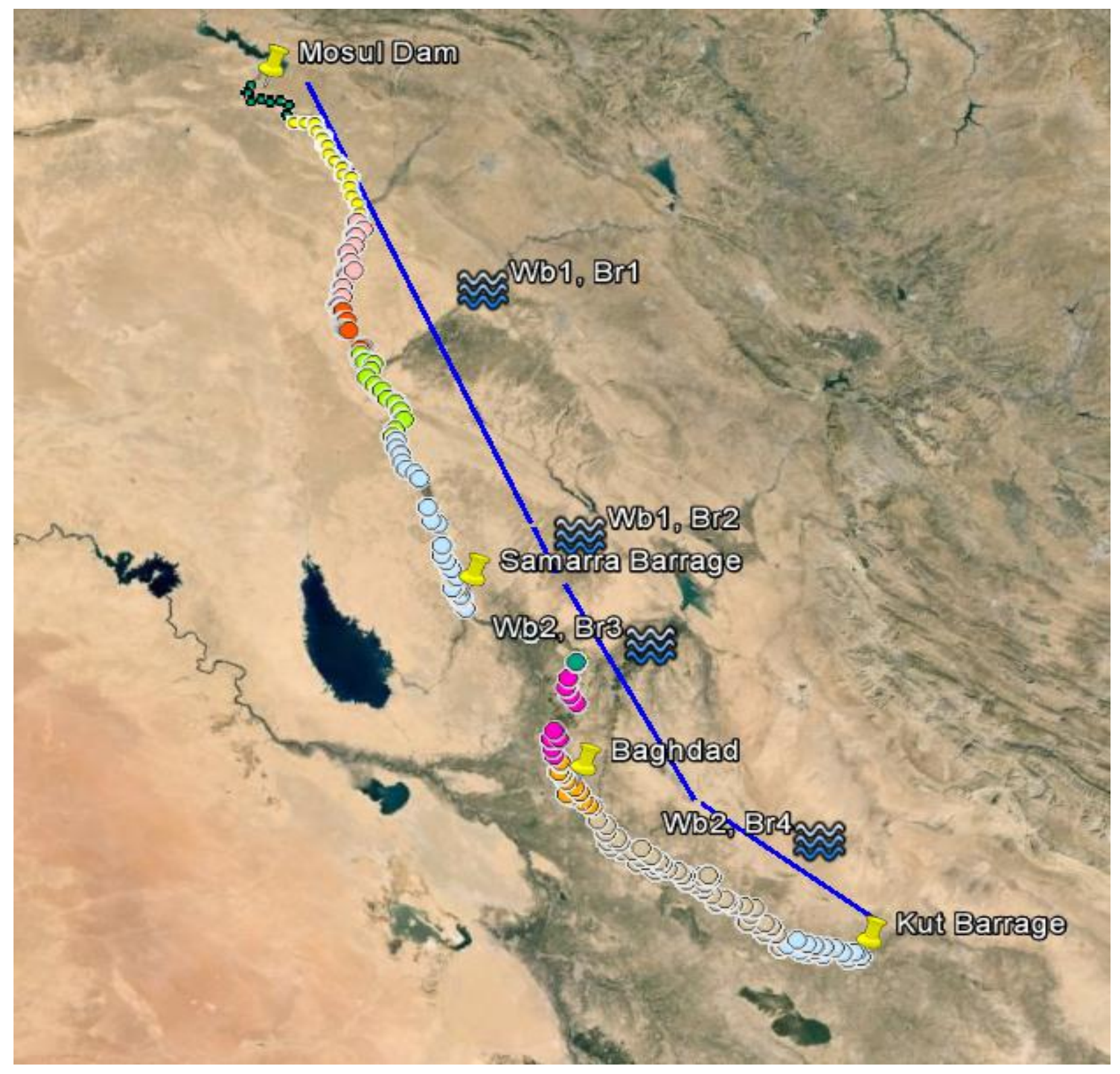

Figure 15: Study area with waterbodies and branches (Google Earth). 
As mentioned above, there is a structure downstream of each waterbody. Samarra Barrage (figure 16) controls the flow of Tigris River and prevents Baghdad city and downstream cities from flooding. In 1956, Samarra Barrage started to divert water from Tigris River to Tharthar Lake during the flood season. The left channel in figure 15 is the diversion channel, while the right channel is the main stream of the Tigris River. A closer Arial imagery of this diversion can be seen in figure 17.

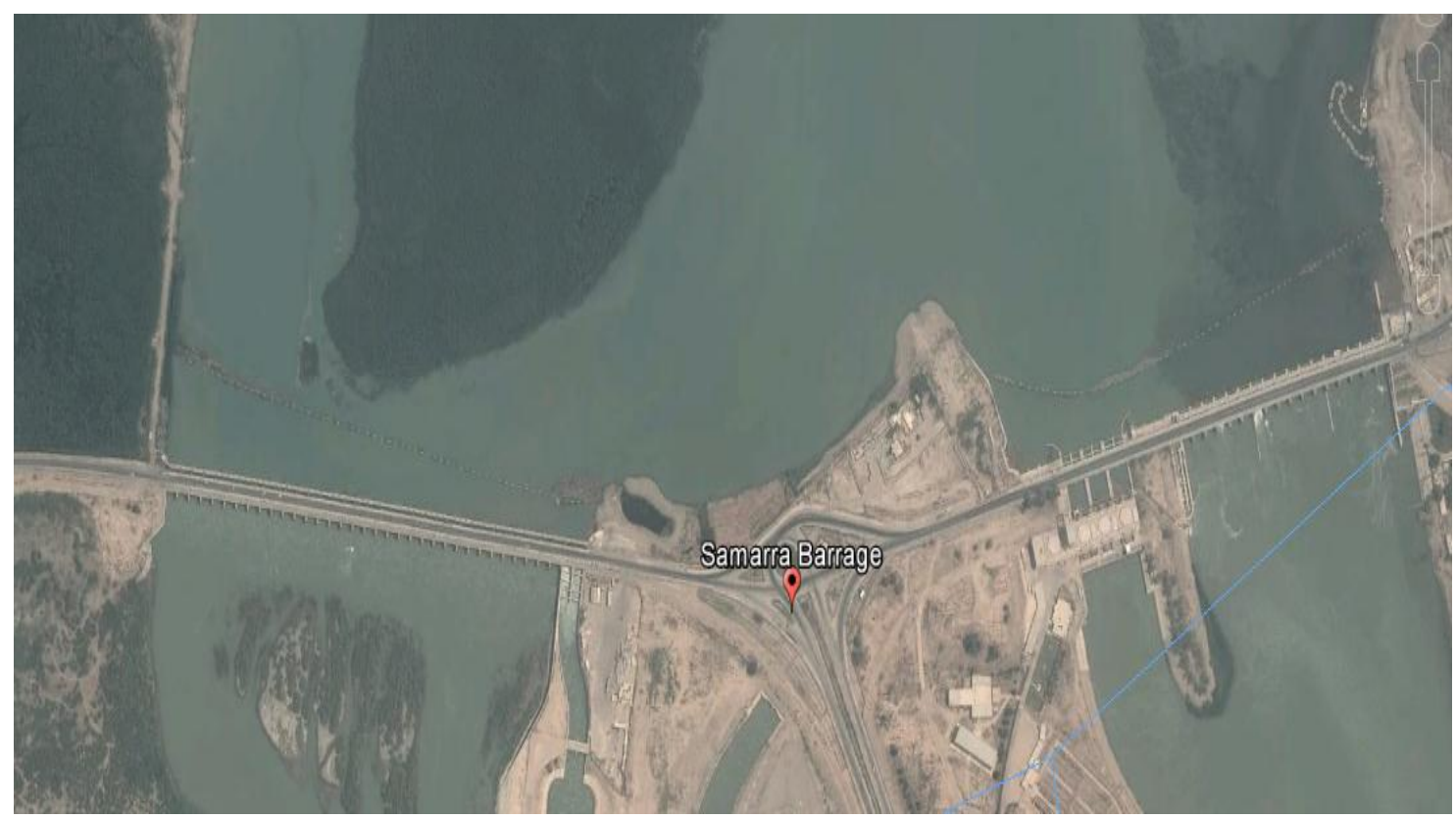

Figure 16: Samarra Barrage with two channels (Google Earth).

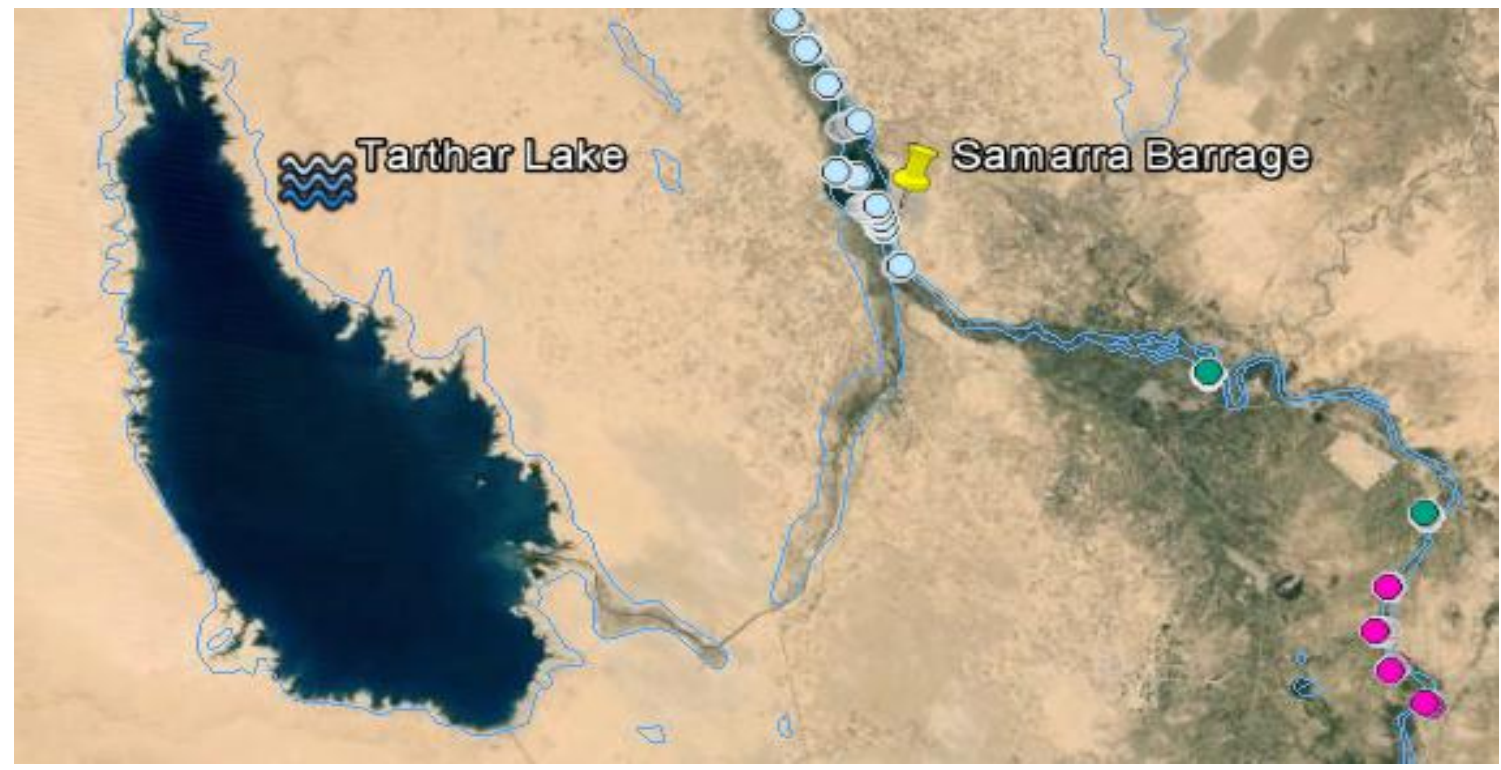

Figure 17: Diversion of water from Tigris River to Tharthar depression (Google Earth). 


\subsection{Water Quality in Iraq}

Water quality gives an indication of how well and healthy the water is for human consumption. Many natural factors or even human made activities affect water quality. Petroleum products, pesticides, wastewater, and toxic chemicals are some of these factors that restrict the water use. Water quality in Iraq is regulated by both Iraqi standards and the health organization guidelines. The quality of drinking water does not meet WHO standards or Iraqi national water quality standards (In Iraq, the quality of water used for drinking and agriculture is poor and violates both Iraqi and health organization guidelines. To illustrate that, the Biological Oxygen Demand (BOD) which is representing the degree of water pollution by organic material was equal to 36.2 $\mathrm{mg} / \mathrm{L}$ that is three times more than the national limit of $10 \mathrm{mg} / \mathrm{L}$ (Water in Iraq Factsheet, 2013). Due to the decreased flow released from Turkey and increased irrigation return water, Tigris River has poor water quality. Therefore, total dissolve solids (TDS) concentrations in the Tigris have been increased dramatically downstream Baghdad city compared with TDS values at the Turkey-Iraqi border. TDS mitigation in Iraq is one of the big concerns because it directly affects water consumption especially for irrigation purposes.

\subsection{Total Dissolved Solids (TDS)}

Total dissolve solids (TDS) is one of many water quality parameters and refers to any salts, minerals, metals, cations (positive ions), and anions (negative ions) dissolved in water. Generally, TDS is a measure of the combination of both organic and inorganic substances. Usually TDS values are expressed in units of mg per unit volume of water $(\mathrm{mg} / \mathrm{L})$. Many constituents such as calcium, bicarbonate, nitrate, magnesium, iron, chloride, potassium, sodium, and phosphate contribute to the TDS concentrations in river water. To reduce TDS in the water system, common water purification methods such as carbon filtration, distillation, reverse osmoses (RO), and deionization (DI) have been used. River Water can be classified by the amount of TDS as (Ela, 2007):

- fresh water $<1500 \mathrm{mg} / \mathrm{L}$ TDS

- brackish water 1500 to $5000 \mathrm{mg} / \mathrm{L}$ TDS

- saline water > $5000 \mathrm{mg} / \mathrm{L}$ TDS 


\subsection{Total Dissolved Solids in Tigris River.}

Total dissolved solids concentrations are highly affect irrigation water. Rising salinity in the Tigris basin is causing soil degradation and impacting surface and GW quality. TDS values of the Tigris water at the Turkish Iraqi border is about $280 \mathrm{mg} / \mathrm{L}$ and it reaches more than 1800 $\mathrm{mg} / \mathrm{L}$ in Basra (Al-Ansari, 2013). Salinization is mainly caused by intensive irrigated agriculture and high evaporation rates. Total dissolved solids concentrations in Tigris River at Mosul Dam, Samarra city, Baghdad city, and Kut city for the year 2009 were provided from the national center for water resources management in Iraq (figure 18).

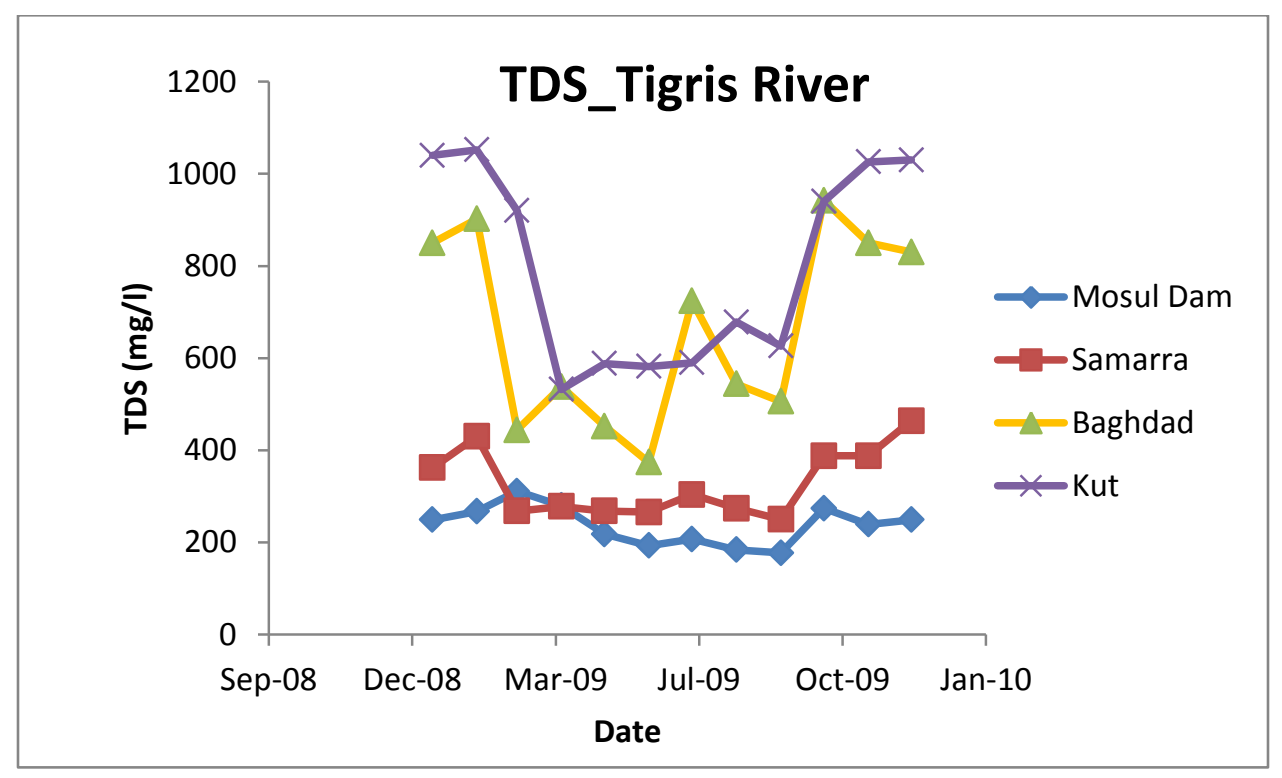

Figure 18: Total dissolved solids TDS in Tigris River.

It can be clearly seen from figure 18 that TDS concentrations increase significantly from Mosul Dam down to Kut city. One of the major reasons for this dramatic increase in TDS is related to irrigation return flow to the main stream of Tigris River. Also, flow from Tharthar depression to the Tigris is another cause of increasing TDS concentrations downstream Baghdad city. 
Figure 19 depicts the difference in TDS concentrations between Samarra Barrage and Tharthar Lake as some of the Tigris flood water is diverted at Samarra Barrage to Tharthar Lake which is heavily saline. The water then is redirected for use in the Tigris River system after salts have been washed. According to Al-Ansari (2013), 50\% of irrigated areas are of medium salinity and $20 \%$ are of slightly saline.

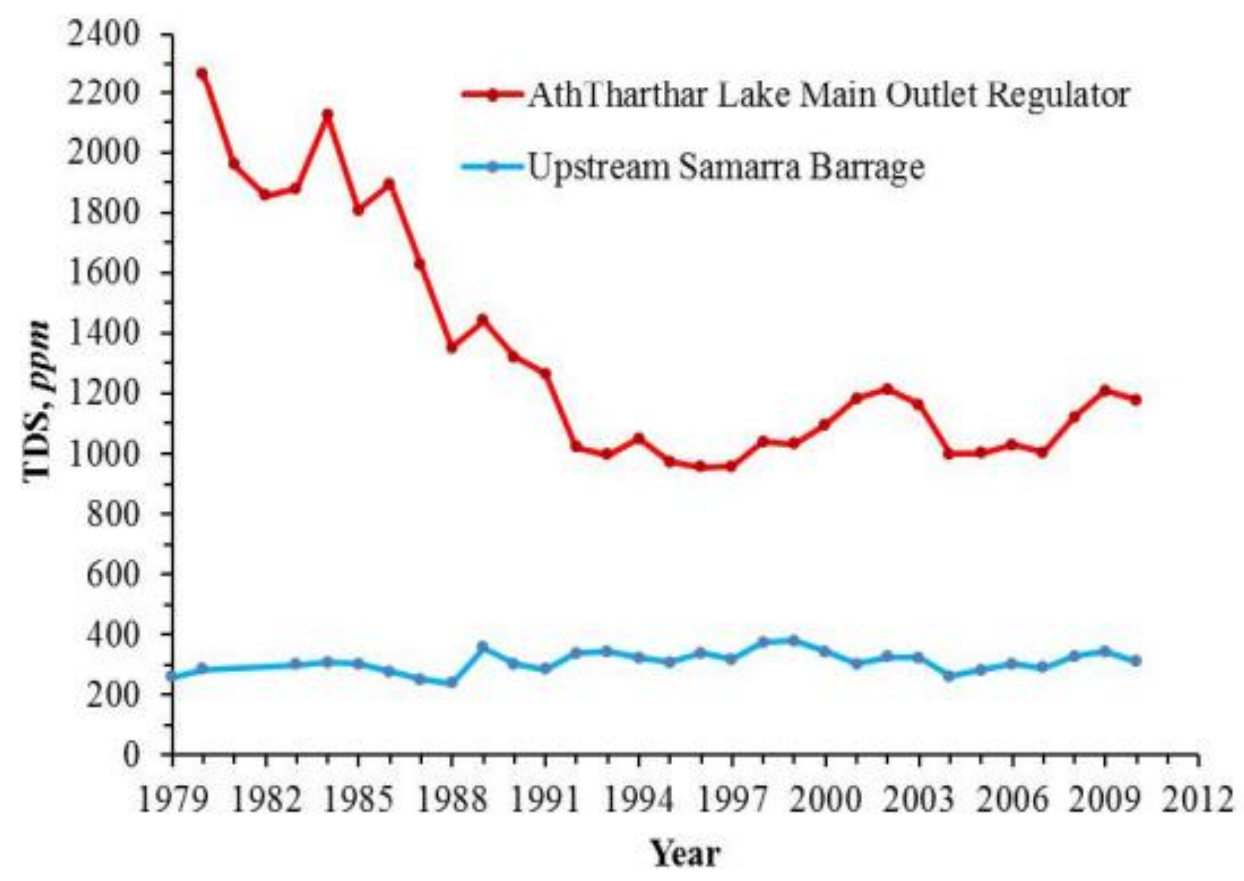

Figure 19: Total dissolved solids concentrations at Samarra Barrage and at the outlet of the Tharthar Lake (CEB, 2011). 


\subsection{CE-QUAL-W2 Model}

CE-QUAL-W2 is a two-dimensional (longitudinal and vertical) water quality model developed by the U.S. Army Corps of Engineers and Portland State University. W2, as it is commonly called, simulates lake circulation, stage, vertical and horizontal velocities, water temperature, and a host of water quality constituents including nutrients, algae, dissolved oxygen, and suspended sediment. W2 has been applied to hundreds of reservoirs all over the world and is capable of simulating water temperatures to a typical accuracy of $0.5-1.0^{\circ} \mathrm{C}$ (Cole and Wells 2014).

\subsection{CE-QUAL-W2 Specification}

CE-QUAL-W2 allows the specification of:

- Waterbodies (a collection of model branches that have similar turbulence closure and water quality parameter values and meteorological forcing for a river or a reservoir).

- Branches (a collection of model segments with variable model slope; a river with different slopes or a reservoir with multiple sidearms).

- Segments (a longitudinal segment of length DX).

- Layers (a vertical layer of height DZ).

\subsection{User Requirement}

In order to start with $\mathrm{W} 2$ model, the user need to be an expert in:

- Hydrodynamics

- Numerical Methods

- Aquatic Chemistry

- Aquatic biology

- Computer science

- Data assembly and reconstruction

- Statistics 


\subsection{Input Data Preparation}

The follow input files should be developed to run W2 model

- Bathymetry

- Meteorological data

- Shade file

- Wind Sheltering

- Initial conditions

- Boundary conditions

- In-river water quality, water level, flow for calibration

- Hydraulic and kinetic parameters

\subsubsection{Bathymetry}

To setup bathymetry of any study area, topographic map, sediment range survey, and volumearea- elevation table or cross-sections for rivers should be available. Bathymetry of Tigris River has been provided by Water Resources Ministry in Iraq in a form of $(\mathrm{X}, \mathrm{Y}, \mathrm{Z})$ cross-sections with $5 \mathrm{~km}$ increment (figure 20).

\begin{tabular}{|c|c|c|c|}
\multicolumn{4}{c|}{ Tigr $490+00 O \mathrm{Km}$} \\
\hline$X$ & $Y$ & $Z$ & Station \\
\hline 436403 & 3715216.6 & 30.87 & 0.6126 \\
\hline 436672 & 3715192.2 & 30.34 & 270.46 \\
\hline 436829 & 3715182.7 & 28.76 & 427.57 \\
\hline 436921 & 3715177.7 & 27.54 & 519.41 \\
\hline 436943 & 3715179.4 & 26.47 & 541.74 \\
\hline 436953 & 3715179 & 25.36 & 551.5 \\
\hline 436966 & 3715177.9 & 24.47 & 564.15 \\
\hline 436993 & 3715176 & 23.37 & 591.75 \\
\hline 437038 & 3715173.7 & 24.65 & 636.53 \\
\hline 437059 & 3715174.5 & 26.47 & 657.57 \\
\hline 437076 & 3715175.5 & 27.54 & 674.04 \\
\hline 437141 & 3715180.2 & 28.87 & 738.68 \\
\hline 437240 & 3715175.5 & 29.76 & 837.82 \\
\hline 437355 & 3715175.5 & 30.54 & 952.98 \\
\hline
\end{tabular}

Figure 20: Tigris River Bathymetry example as provided from WRM (2014), Iraq. 
A cross section graph (figure 21) for each cross section and for the whole study area has been developed to inspect what a cross-section looks like. Geographical Information system (GIS) is implemented to visualize river morphology and to project all $\mathrm{x}, \mathrm{y}$, and $\mathrm{z}$ points with a projection UTM 1984 Zone 38N (North) and a datum GCS WGS 1984 (figure 14). Figure 22 shows projected points on the Tigris River with an increment of $5 \mathrm{~km}$, but after projecting all crosssections provided from (WRM), it is found that there are occasional gaps need to be filled. It can be clearly seen from figure 22 that there are two gabs $(40 \mathrm{~km})$ need to be linearly interpolated to get cross-sections with $5 \mathrm{~km}$ increment. It is worth to mention that bathymetry development is really time consuming process in terms of projection, interpolation, and calculation layers width and orientation.

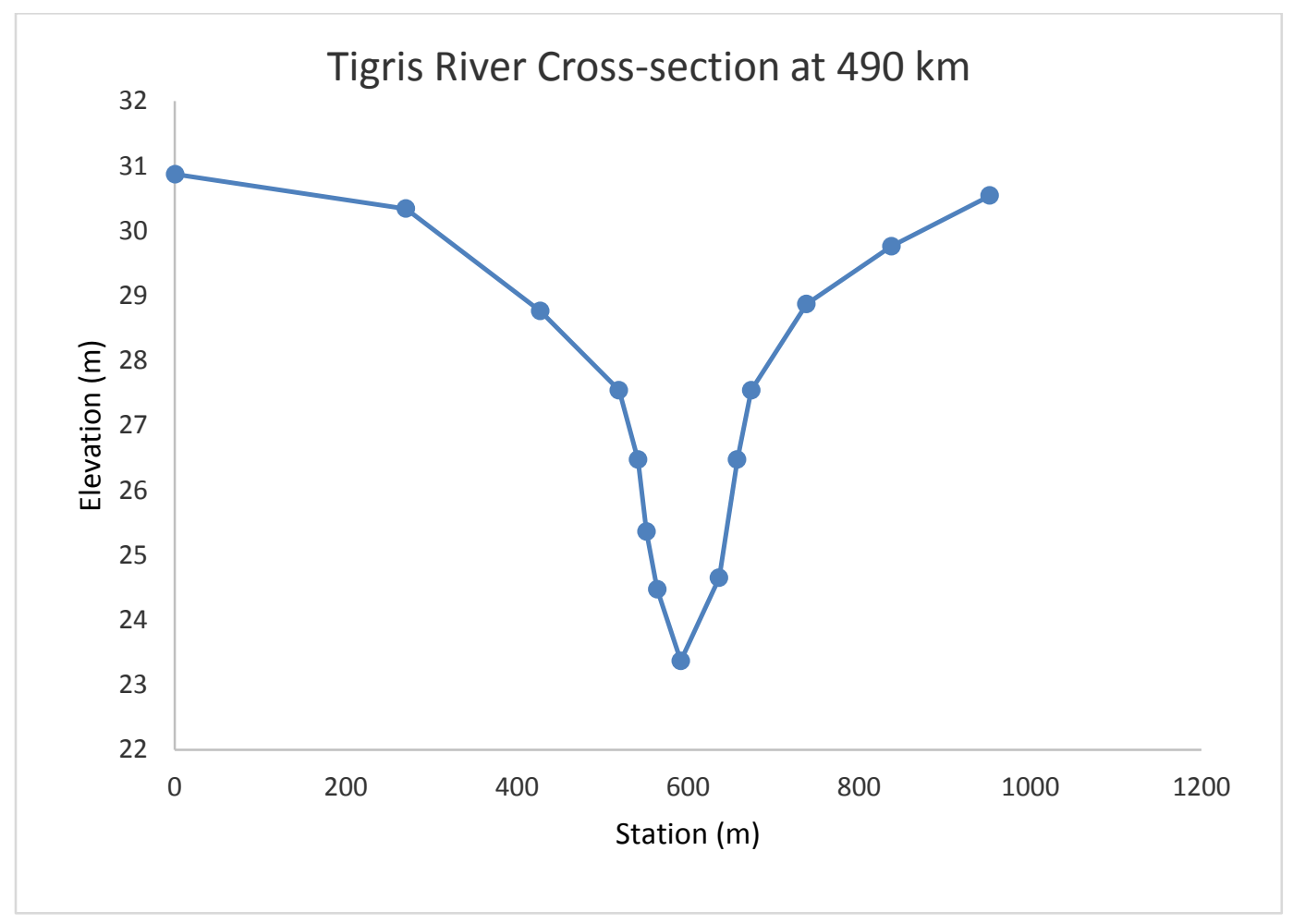

Figure 21: Tigris River cross-section at $490 \mathrm{~km}$. 


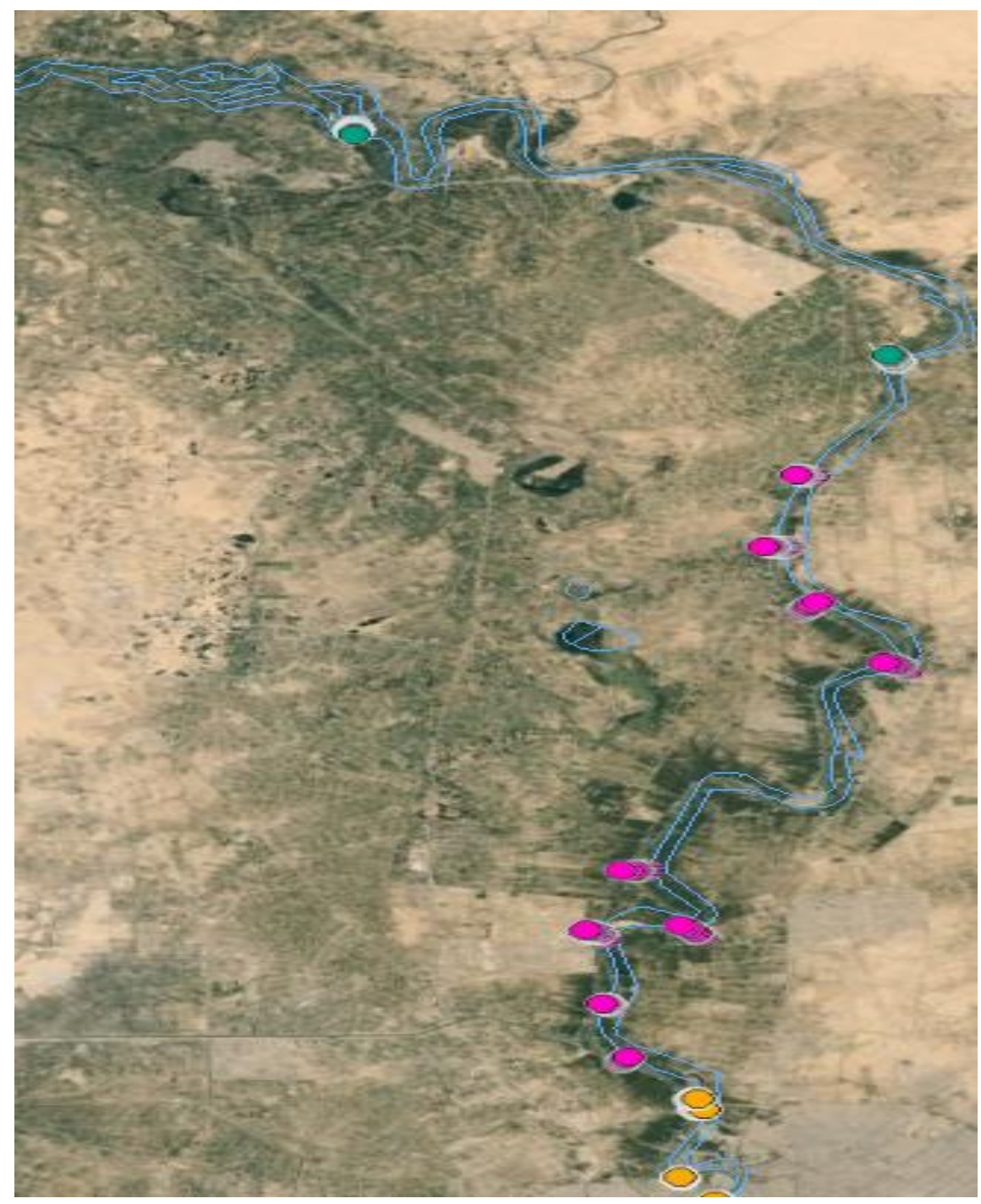

Figure 22: Gaps between Projected points on Tigris River (Google Earth).

FORTRAN code is used to develop layers width for all segments. Each segment has ten active layers (figure 23) and two inactive layers surrounded the layer from top and bottom, the layer's height is one meter. Another FORTRAN code is used to develop segments orientation. For missing cross-section with no longitude and latitude, orientation is determined using a manual compass. The way to determine orientation is explained in figure 24 . Figure 25 shows Tigris River's orientation constructed by W2 model. 


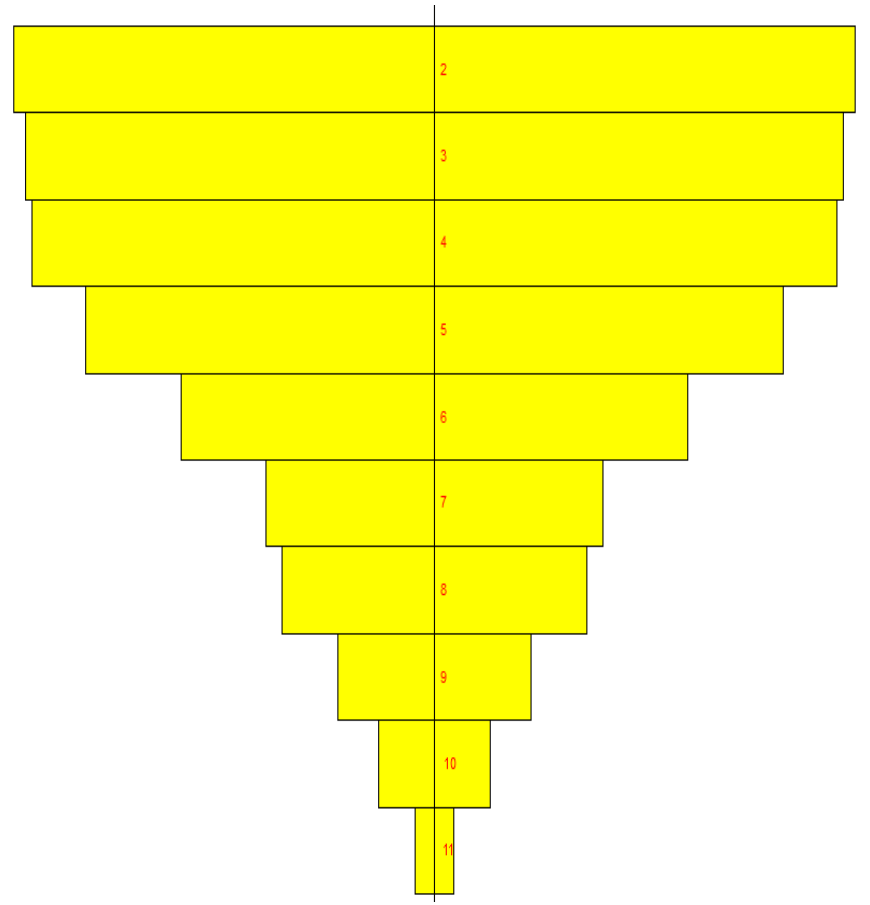

Figure 23: Segment \# 3 with ten active layers constructed by W2 model.

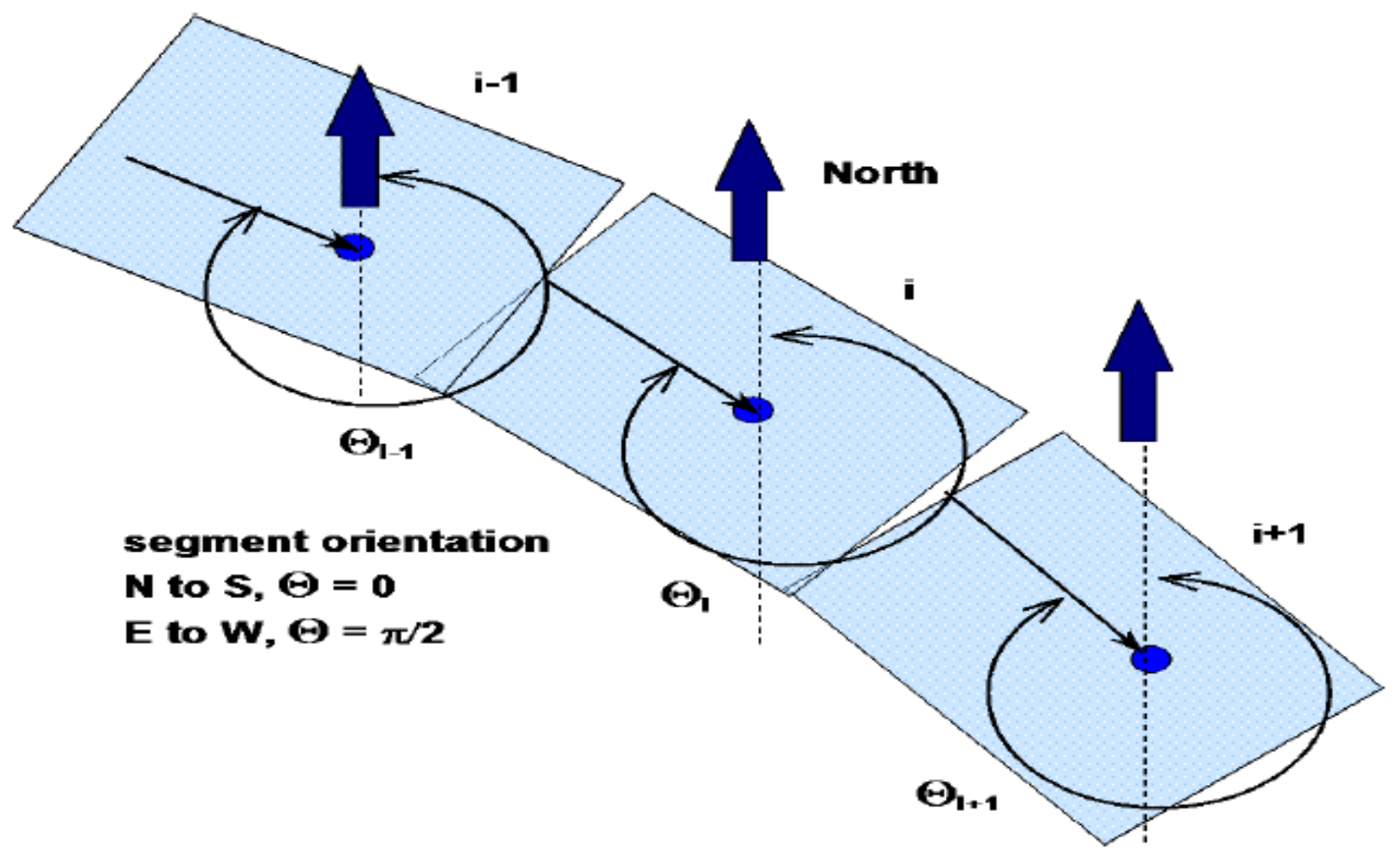

Figure 24: Segment orientation estimation (Cole and Wells 2014). 


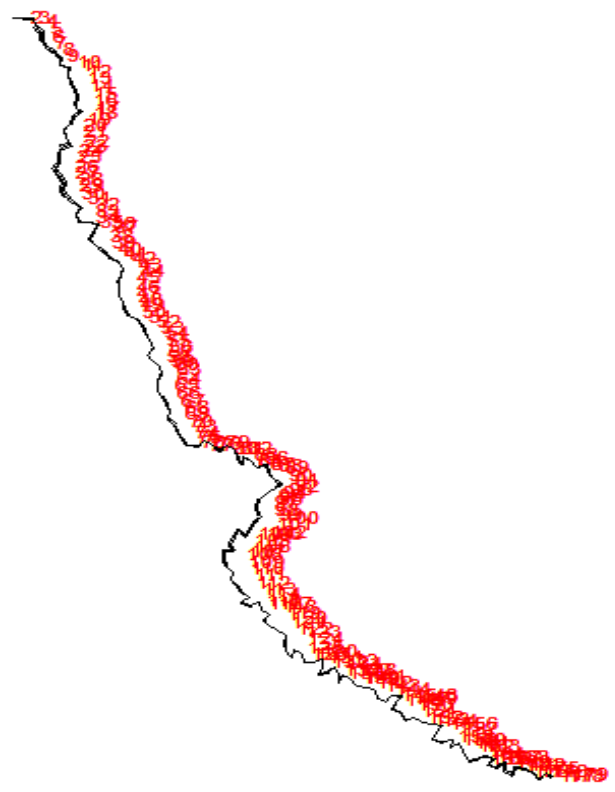

Figure 25: Tigris River study area constructed by W2 model.

\subsubsection{Tigris River Slope}

Tigris River's bottom elevation is estimated using the provided bathymetry data from water resources ministry in Iraq. The bottom elevation at each cross section is plotted to estimate the river's slope. The slope of Tigris River from Mosul Dam to Kut Barrage $(880 \mathrm{~km})$ is revealed in figure 26 .

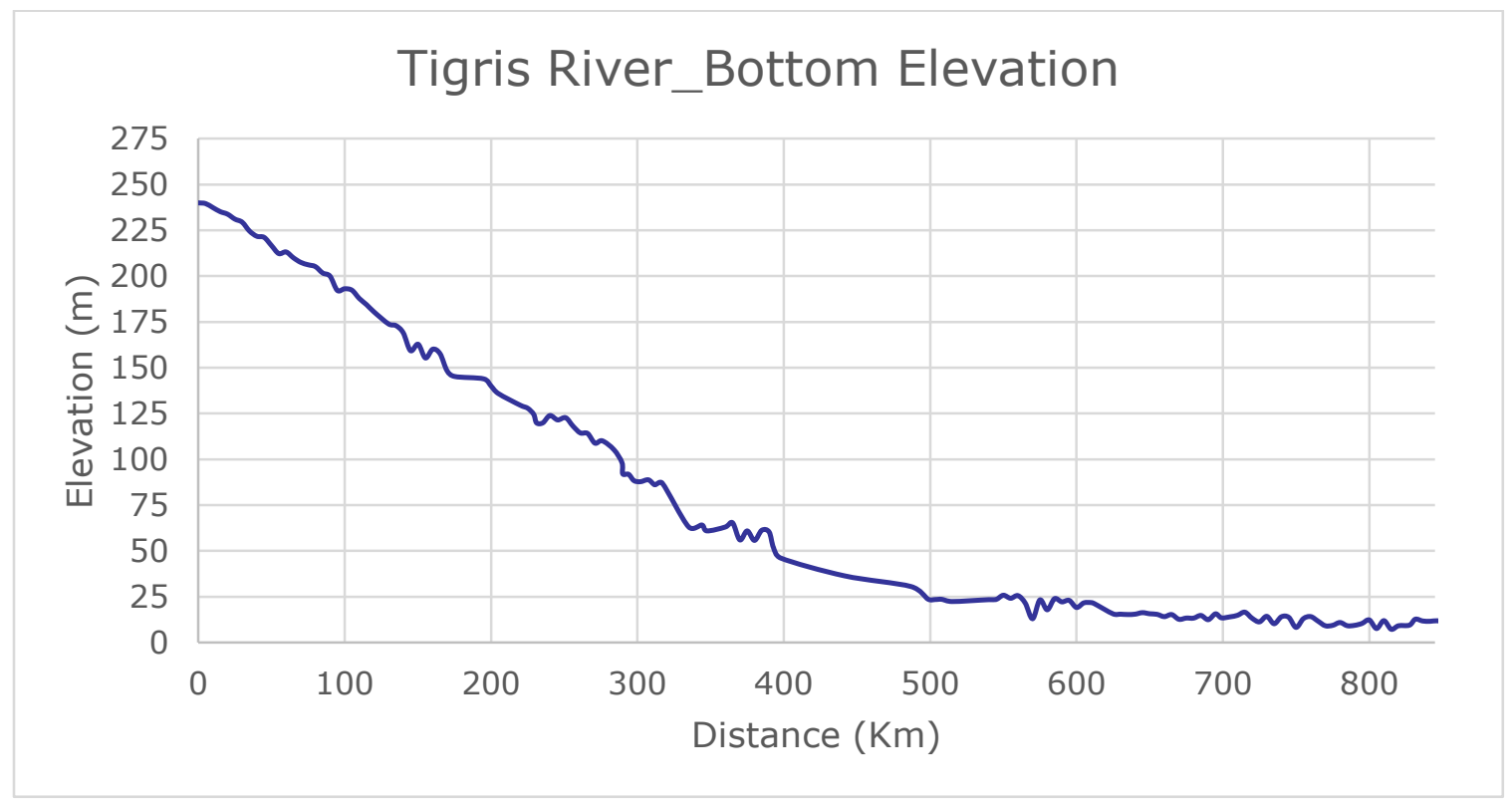

Figure 26: Bottom Elevation of Tigris River from Mosul Dam to Kut Barrage. 


\subsubsection{Computational Grid}

The grid is constructed with a total segments of 190 in which 182 active segments and 8 inactive segments. Each segment consists of ten active layers and two inactive layers. The total active segments for each branch from upstream to downstream be $69,8,55$, and 50 respectively. Upper zab crosses Tigris River at segment 14, while Lower Zab crosses Tigris River at segment 46. Finally, Diyalah River crosses the Tigris at segment 132. A computational grid example from W2 manual (Cole and Wells 2014) is shown in figure 27. It can be clearly seen that all blue cells are active segments while gray cells are in active segments.

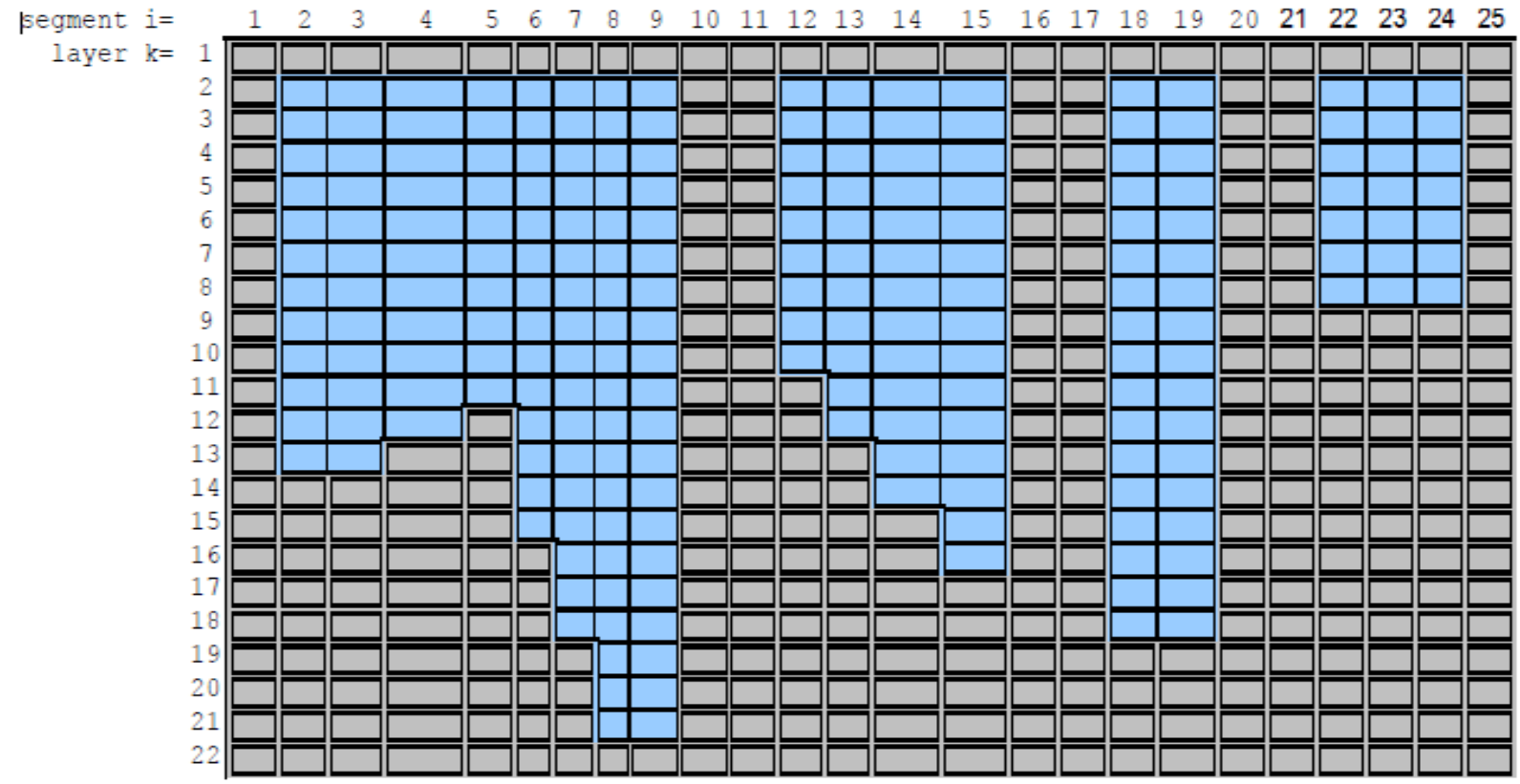

Figure 27: A computational grid example (Cole and Wells 2014).

\subsubsection{Initial Conditions}

Initial conditions of Tigris River W2 model include control file, simulation period, inflows/outflows, temperature/concentration, and waterbody type. The control file has been developed using W2 GUI. Tigris River model has been simulated for one water year, October 2008 to October 2009, since all flow data are available for that water year. Temperature and metrological data are adopted from Long Lake River system in Washington. Total dissolved solids (TDS) is the main concern in Iraq, so it is the state variable in this project. Also, waterbody type is fresh water. 


\subsection{Computation of the Water Balance}

As we have been provided with flowrate $\left(\mathrm{m}^{3} / \mathrm{s}\right)$ data at Mosul Dam, Tikrit, Samarra Barrage, Baghdad, and Kut Barrage, initial flow conditions at Mosul Dam and boundary conditions at both Samarra and Kut Barrages have been developed. Monthly average flowrates of Upper Zab, Lower Zab, Ahudaim River, and Diyalah River have been extracted from a report done by Central Statistical Organization, Ministry of Planning in Iraq 2009 (in Arabic). Flow balance for each branch including all tributaries is done along the entire study area. Evaporation is taken into account by running W2 model without distributed tributary. Then, flow balance is done to account for distributed water at each branch. Flow balance at the first waterbody (figure 28) is done for both branches, $\mathrm{Br} 1$ and $\mathrm{Br}$ 2. From Mosul Dam to Tikrit city, Br1, two major tributaries Upper Zab and Lower Zab contribute water to Tigris River. Therefore, distributed flowrate is estimated from equation (1). It is worth to mention that W2 model considers distributed flowrate as either positive value (into the river) or negative value (out from the river)

$\mathrm{Q}_{\mathrm{d}}=\mathrm{Q}_{\mathrm{T}^{-}} \mathrm{Q}_{\mathrm{M}^{-}}-\mathrm{Q}_{\mathrm{U}^{-}}-\mathrm{Q}_{\mathrm{L}}$

Where:

$\mathrm{Q}_{\mathrm{d}}$ : Flowrate for distributed tributary $\left(\mathrm{m}^{3} / \mathrm{s}\right)$.

$\mathrm{Q}_{\mathrm{T}}$ : Flowrate at Tikrit $\left(\mathrm{m}^{3} / \mathrm{s}\right)$.

$\mathrm{Q}_{\mathrm{M}}$ : Flowrate at Mosul Dam $\left(\mathrm{m}^{3} / \mathrm{s}\right)$.

QU: Flowrate at Upper Zab $\left(\mathrm{m}^{3} / \mathrm{s}\right)$.

$\mathrm{Q}_{\mathrm{L}}$ : Flowrate at Lower $\mathrm{Zab}\left(\mathrm{m}^{3} / \mathrm{s}\right)$.

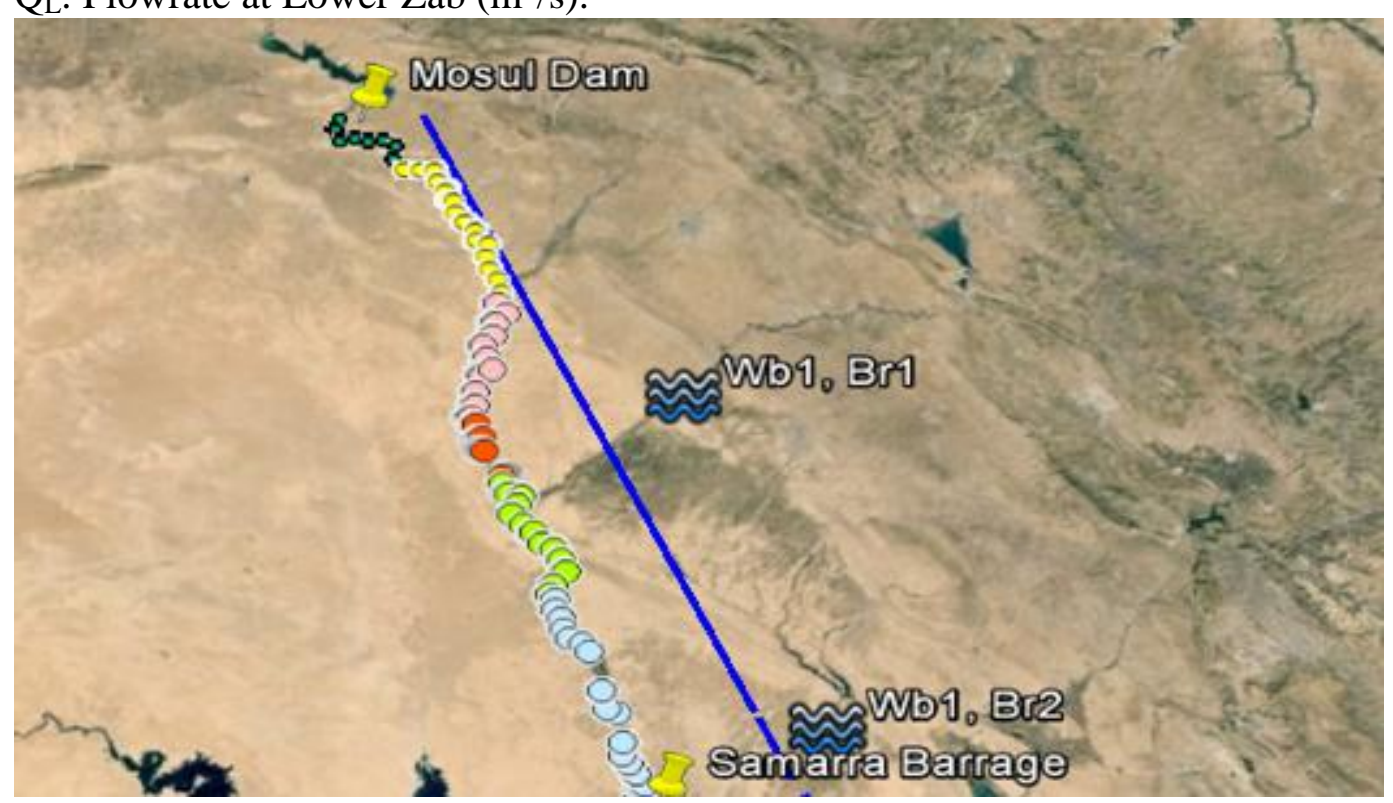

Figure 28: Flow balance at the first waterbody (Google Earth). 
No tributary joins Br2 between Tikrit and Samarra Barrage, therefor distributed flowrate is estimated by flowrate difference between Samarra Barrage and Tikrit.

Figure 29 shows the second waterbody in which Ahudaim River joins Br3, while Diyalah River joins $\mathrm{Br} 4$. As done before at $\mathrm{Br} 1$, distributed flowrate for $\mathrm{Br} 3$ is estimated by flow balance between Baghdad and Samarra, equation (2). Equation (3) represents flow balance for Br4.

$\mathrm{Q}_{\mathrm{d}}=\mathrm{Q}_{\mathrm{B}}-\mathrm{Q}_{\mathrm{S}}-\mathrm{Q}_{\mathrm{A}}$

Where:

$\mathrm{Q}_{\mathrm{d}}$ : Flowrate for distributed tributary $\left(\mathrm{m}^{3} / \mathrm{s}\right)$.

$\mathrm{Q}_{\mathrm{B}}$ : Flowrate at Baghdad $\left(\mathrm{m}^{3} / \mathrm{s}\right)$.

$\mathrm{Q}_{\mathrm{S}}$ : Flowrate at Samarra Barrage $\left(\mathrm{m}^{3} / \mathrm{s}\right)$.

$\mathrm{Q}_{\mathrm{A}}$ : Flowrate at Ahudaim River $\left(\mathrm{m}^{3} / \mathrm{s}\right)$.

$\mathrm{Q}_{\mathrm{d}}=\mathrm{Q}_{\mathrm{K}}-\mathrm{Q}_{\mathrm{B}}-\mathrm{Q}_{\mathrm{D}}$

Where:

$\mathrm{Q}_{\mathrm{d}}$ : Flowrate for distributed tributary $\left(\mathrm{m}^{3} / \mathrm{s}\right)$.

$\mathrm{Q}_{\mathrm{K}}$ : Flowrate at Kut Barrage $\left(\mathrm{m}^{3} / \mathrm{s}\right)$.

$\mathrm{Q}_{\mathrm{B}}$ : Flowrate at Baghdad $\left(\mathrm{m}^{3} / \mathrm{s}\right)$.

$\mathrm{Q}_{\mathrm{D}}$ : Flowrate at Diyalah River $\left(\mathrm{m}^{3} / \mathrm{s}\right)$.

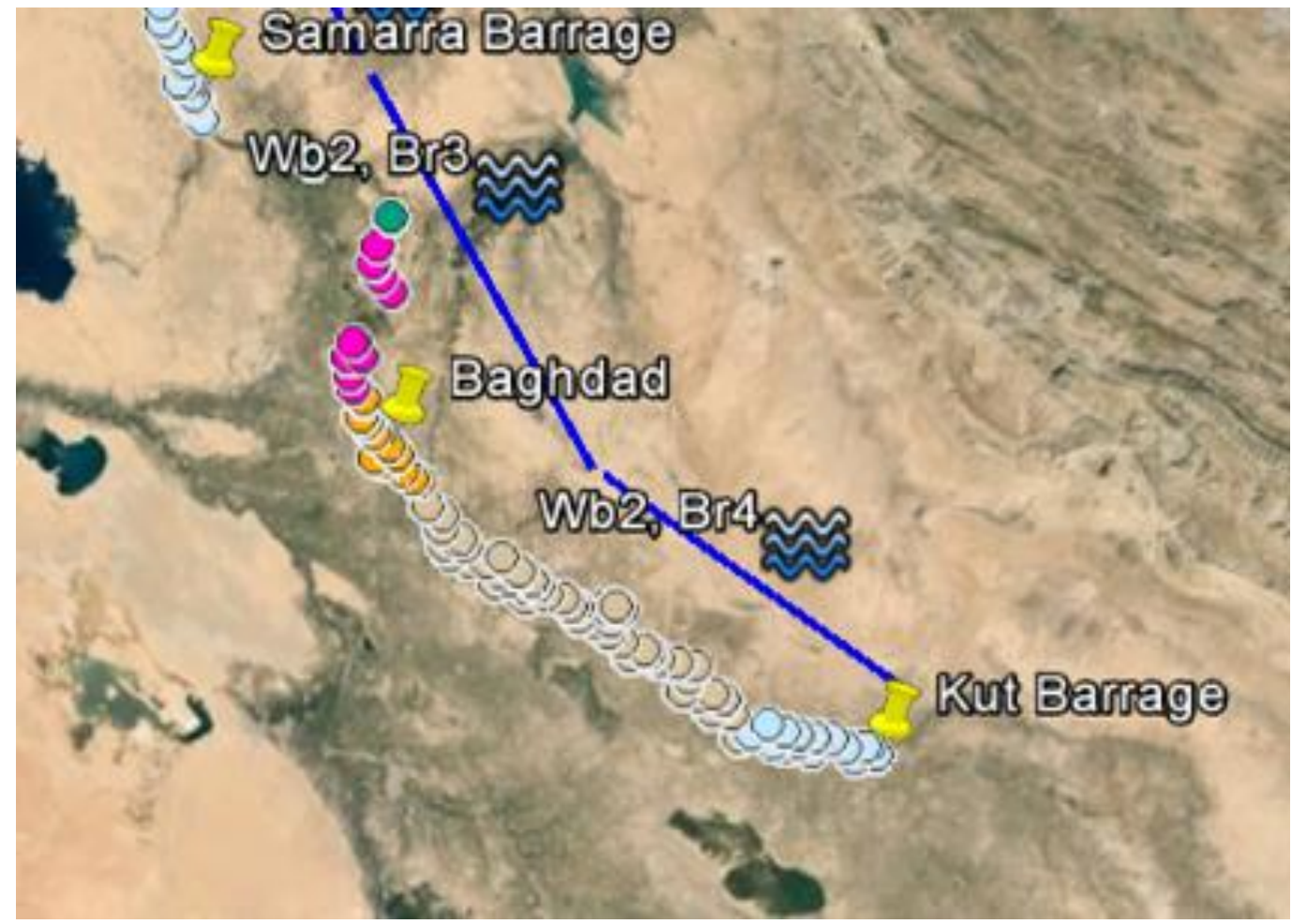

Figure 29: Flow balance at the second waterbody (Google Earth). 


\subsection{Construction of Tigris River Model}

CE-QUAL-W2 model is utilized to simulate flow, temperature, and total dissolved solids (TDS) of Tigris River model. After developing all files required to run the model, W2 starts to run.

Figure 30 shows the main window of W2 model while it is running.

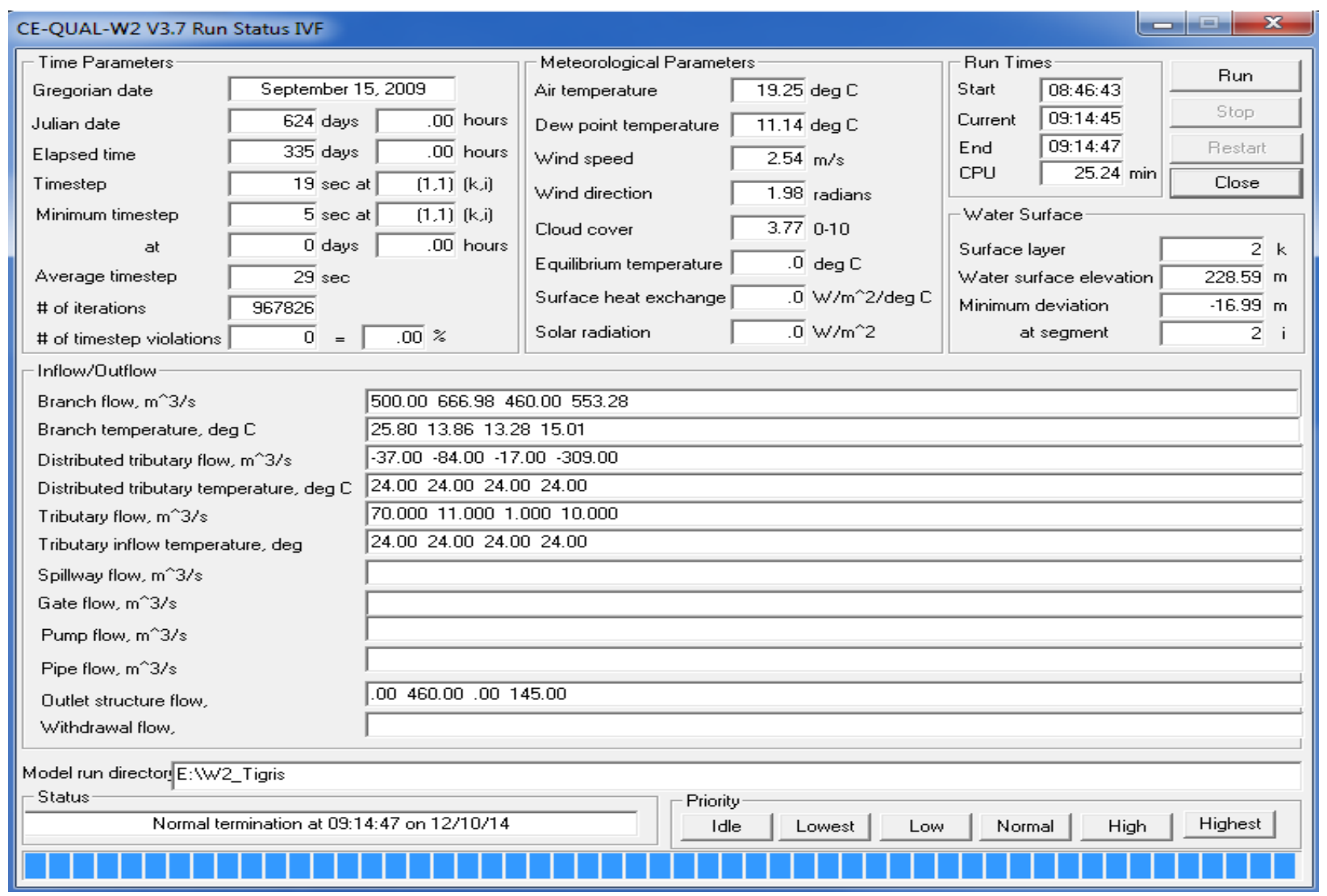

Figure 30: CE-QUAL-W2 window of Tigris River model. 


\subsection{Conclusions}

CE-QUAl_W2 model has been implemented on Tigris River in Iraq to simulate flowrate, temperature, total dissolved solids (TDS). A study area from Mosul dam to Kut Barrage (880 $\mathrm{km}$ ) has been simulated by W2 model. All input files required by W2 model have been developed to run a non-calibrated model. Development of bathymetry input file in terms of filling cross-sections gaps, estimation of segment's orientation, and calculating layers width for each segment is the most consuming time in this work since the model simulates a long retch of $880 \mathrm{~km}$.

The salinity of Tigris River in Iraq has dramatically increased from Mosul Dam to Kut Barrage due to the regulated water quantity from Turkey especially after starting the Greater Anatolia Project (GAP), the flow from Tharthar Lake to the Tigris, and irrigation return flow within Iraq. Downstream Baghdad city, salinity has increased significantly to a point makes the river water no longer appropriate for both human consumption and irrigation purposes.

\subsection{Future Recommendations}

Estimation of surface water temperature and turbidity of Tigris River remotely is a good tool to get some data that are needed to pursue this work. Unfortunately, water surface temperature data are unavailable in Iraq; therefore, remote sensing should be utilized. Furthermore, depth and width should be estimated at each cross-section as a function of flowrate by implementing Leopold approach. 


\subsection{REFERENCES}

Ali, A. A., Al-Ansari, N. A., and Knutsson, S., (2012). "Morphology of Tigris River within Baghdad city.” J. Hydrol. Earth Syst. Sci., 16, 3783-3790.

Altinbilek, D., (2004). “Development and management of the Euphrates-Tigris basin.” J. Water Res. Development, 20, 1, 15-33.

Al-Anbari, R. A., Mahmood, T. A., and Yousif, W. F., (2006). "Hydraulicgeometry of the Tigris River from Mosul to Bejee related to water temperature modeling." J. Env. Hydrol., 14, 1-11.

Al-Ansari, N. A. (2013). "Management of water resources in Iraq: perspectives and prognoses." J. Eng., 5, 667-684.

Al-Ansari, N. and Knutsson, S., (2011). "Toward prudent management of water resources in Iraq.” J. Advanced Science and Eng. Res., 1, 53-67.

AL-Janabi, K. W., Alazawi, F. N., Mohammed, M. I., Kadhum, A. A., and Mohamad, A. B., (2011). "Chlorophenols in Tigris River and drinking water of Baghdad, Iraq." Bulletin of Environmental Contamination and Toxicology, 87, 2, 106-112.

Al-Jubori, M.A.M. (1998). "Watercourse flow pattern of the River Tigris between the two Zabs." Ph.D. thesis, Mosul Univ., Iraq.

Al-Marsoumi, A. H., Al-Bayati, K. M., and Al-Mallah, E. A., (2006). "Hydrogeochemical aspects of Tigris and Euphrates Rivers within Iraq: A comparative study." J. RAF. Sci., 17, 2, 34-49.

Al-Obaidy, A. H. M., Abid, H. S., and Maulood, B. K. (2010). "Application of water quality index for assessment of Dokan Lake ecosystem, Kurdistan region, Iraq." J. Water Resources and Protection, 2,792-798.

Al-Obaidy, F. M. Sh. (1996). "Hydrological study of the stage and other characteristics of Tigris River.” M.S. thesis, Mosul Univ., Iraq.

Al-Samak, M.A.S., Al-Saati, B.A, Al-Janabi, F.H., Al-Timimi, A.A. and Ghalib, S.A. (1985). "Iraq-Regional Study.” Vol.1, Dar Al-Kutib, Mosul Univ., P304 (in Arabic).

Al-Shahrabaly, Q.M. (2008). "River discharges for Tigris and Euphrates gauging stations." Ministry of Water Resources, Baghdad (in Arabic).

Beaumont, C., Quinlan, G., and Hamilton, J. (1988). "Orogeny and stratigraphy: Numerical models of the Paleozoic in the eastern interior of North America: Tectonics." 7, 389-416. As cited by Managing water for peace in the Middle East (http://archive.unu.edu/unupress/unupbooks/80858e/80858E04.htm) 
Beaumont, P. (1996). "Agricultural and environmental changes in the upper Euphrates catchment of Turley and Syria and their political and economic implications.” J. Applied Geography, 16, 2, 137-157

Burnham, G., Lafta, R., Doocy, S., and Roberts, L., (2006). "Mortality after the 2003 Invasion of Iraq: A cross-sectional cluster sample survey.” Lancet, 368, 9545, 1421-1428.

Central Statistical Organization, Ministry of Planning in Iraq (2009), Environmental Report (in Arabic). Available at: http://www.cosit.gov.iq/documents\%5Cstatistics_ar\%5CEnvironment Full Report, pdf.

Central Statistical Organization, Ministry of Planning in Iraq (2009), Environmental Report (in Arabic). Available at: http://www.cosit.gov.iq/documents\%5Cstatistics_ar\%5CEnvironment Full Report, pdf.

Cole, T. M., Wells, S. A. (2014). “CE-QUAl-W2: a two-dimensional, laterally averaged, hydrodynamic and water quality model.” version 3.71. Instruction Report EL-2000. US Army Engineering and Research Development Center, Vicksburg

Consulting Engineering Bureau (CEB), (2011). Lakes testing study, College of Engineering, University of Baghdad, Iraq.

Ela, W. P., (2007).” Introduction to Environmental Engineering and Science.” Prentice Hall, 3rd ed. ISBN 0-13-148193-2.

Gatte, M. T. and Kadhim, R. A. (2012). "Hydro Power.” Energy Conservation, Ahmed, A. Z. Chapter 4. ISBN: 978-953-51-0829-0, Intec, DOI: 10.5772/52269. Available from:

http://www.intechopen.com/books/energy-conservation/hydro-power

Google Earth.

Iraq the lasting love http://iraqthelastinglove.blogspot.com/2009/09/more-from-iraqs-olddays.html.

Kadhem, A. J., (2013). “Assessment of water quality in Tigris River-Iraq by using GIS mapping." J. Natural Resources, 4, 441-448.

Ministry of Water Resources-Iraq (MWR), (2005). Schematic diagram of main control structures in Iraq, General directorate of water resources management, hydrological studies center.

Ministry of Water Resources-Iraq (MWR), (2010). Annual Report, National Centre for Water Resources Management.

Rahi, K. A. and Halihan, T. (2009). "Changes in the salinity of the Euphrates River system in Iraq.” J. Reg. Environ. Change, 10, 27-35.

Saad, M. A. H., and Antoine, S. E. (1978). "Limonological studies on the River Tigris, Iraq." I. Environmental Characteristics. J. Hidrobiol., 63, 5, 685-704. 
University of Texas at Austin, (2003). http://www.lib.utexas.edu/maps/middle_east.html

University of Texas at Austin, (2014). http://www.lib.utexas.edu/maps/cia14/iraq_sm_2014.gif

University of Victoria, 2010, Dams in the Tigris Euphrates river basins, online map, http://hdl.handle.net/1828/2400, last access: 29-January-2013.

UN-ESCWA and BGR, 2013, Inventory of Shared Water Resources in Western Asia, United Nations Economic and Social Commission for Western Asia and Bundesanstalt für Geowissenschaften und Rohstoffe, Beirut.

Water Deficit 2003 Article. Cited by "Tigris and Euphrates setting the scene." Available at http://globalwater.pbworks.com/w/page/48791929/Tigris\%20and\%20Euphrates\%20Setting\%20t he\%20Scene

Water in Iraq factsheet (2013), available at: http://www.jauiraq.org/documents/1866/WaterFactsheet.pdf. 